\title{
Integrated Ediacaran chronostratigraphy, Wernecke Mountains, northwestern Canada
}

\author{
Leanne J. Pyle ${ }^{\mathrm{a}, *}$, Guy M. Narbonne ${ }^{\mathrm{a}}$, Noel P. James ${ }^{\mathrm{a}}$, \\ Robert W. Dalrymple ${ }^{\mathrm{a}}$, Alan J. Kaufman ${ }^{\mathrm{b}}$ \\ a Department of Geological Sciences and Geological Engineering, Miller Hall, Queen's University, Kingston, Ont., Canada K7L $3 N 6$ \\ ${ }^{\mathrm{b}}$ Department of Geology, University of Maryland, College Park, MD 20742, USA
}

Received 9 July 2003; accepted 13 January 2004

\begin{abstract}
Terminal Neoproterozoic (Ediacaran, ca. 600-543 Ma) strata of the upper part of the Windermere Supergroup are well-exposed in the Mackenzie Mountains and the Wernecke Mountains of northwestern Canada. Windermere strata in the Mackenzie Mountains contain an exceptional Ediacaran biostratigraphic and isotopic $(\mathrm{C}$ and $\mathrm{Sr})$ record, while the sequence stratigraphic record is subtle throughout this predominantly deep-water succession. Coeval strata in the Wernecke Mountains can be correlated with the succession in the Mackenzie Mountains on a formational level. In contrast to the deep-water setting of the Mackenzies succession, the Werneckes succession preserves a predominantly shallow-water succession amenable to detailed sequence stratigraphy. Integrated lithostratigraphy, chemostratigraphy, biostratigraphy and sedimentology partitions the Wernecke Mountains succession into five depositional sequences and constrains correlation with strata in the Mackenzie Mountains. The siliciclastic and carbonate sediments, deposited along the margin of the proto-Pacific Ocean, record accumulation in continental slope, neritic, and terrestrial paleoenvironments. Distinctive temporal chemostratigraphic and biostratigraphic attributes allow these strata to be correlated with other Ediacaran successions worldwide. Integrating sequence stratigraphy with these attributes is a robust, yet under-utilized correlation tool and is a step toward erecting a more detailed working Neoproterozoic chronostratigraphy. (C) 2004 Elsevier B.V. All rights reserved.
\end{abstract}

Keywords: Terminal Neoproterozoic; Ediacaran; Chronostratigraphy; Sequence stratigraphy; Wernecke Mountains; Chemostratigraphy

\section{Introduction}

The terminal Neoproterozoic (ca. 600-543 Ma) represents a critical time in earth history, marked by the end of the Proterozoic "snowball" glaciations (Hoffman et al., 1998), appearance of the oldest (Ediacaran) metazoans (Glaessner, 1984; Narbonne, 1998; Narbonne and Gehling, 2003) and profound changes in the isotopic composition of seawater (Kaufman and

\footnotetext{
* Corresponding author. Tel.: +1-613-533-6184; fax: +1-613-533-6592.

E-mail address: 1pyle@geol.queens.ca (L.J. Pyle).
}

Knoll, 1995). Paleontological data complemented by isotopic chemostratigraphy, has become a dependable tool for correlating late Neoproterozoic successions at an intra- and inter-basinal level (e.g., Knoll and Walter, 1992; Grotzinger et al., 1995), and sequence stratigraphy adds further resolution in approaching an integrated chronostratigraphy (Christie-Blick et al., 1995). The well-preserved predominantly deep-water succession in the Mackenzie Mountains in northwestern Canada is critical in understanding Neoproterozoic events (Narbonne et al., 1994; James et al., 2001). The coeval, shallower-water succession in the Wernecke Mountains, a nearby but somewhat less 

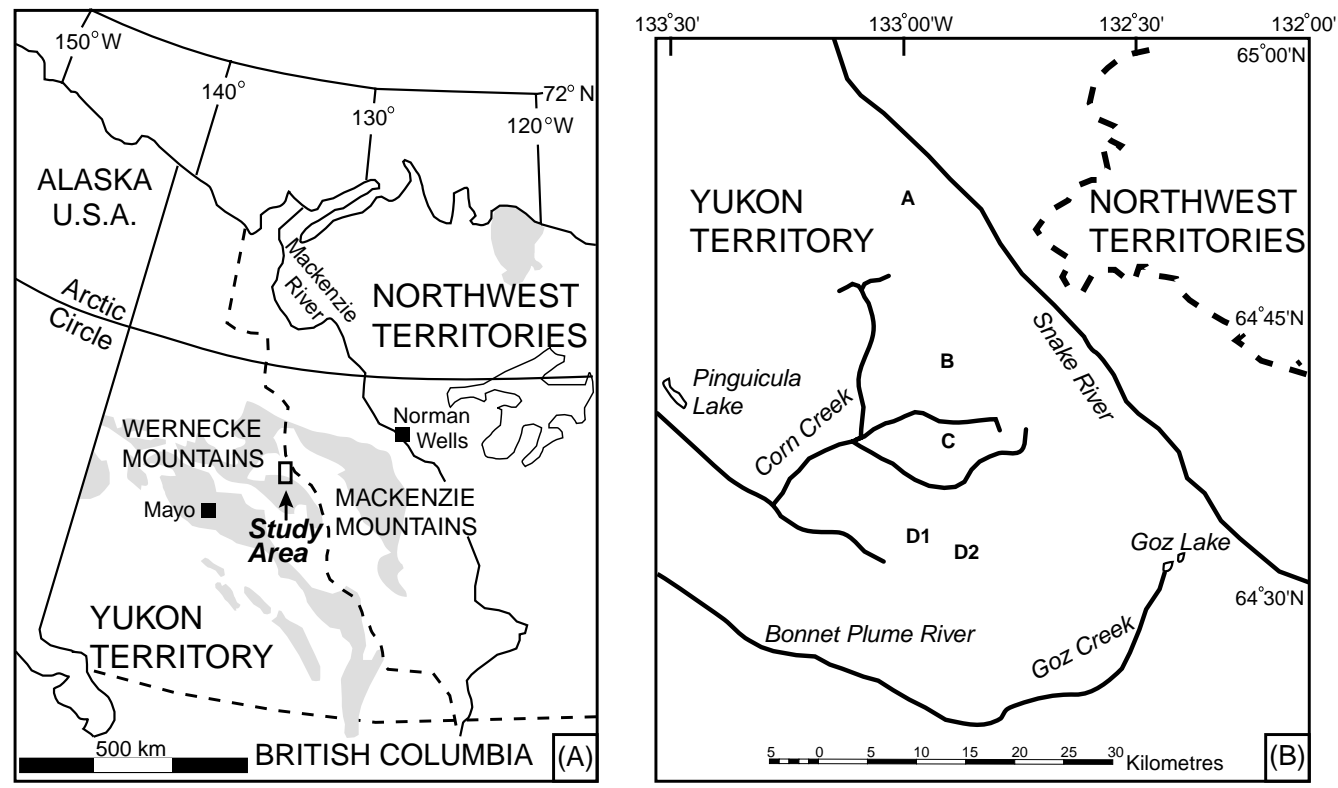

Fig. 1. (A) Location of study area and distribution of Neoproterozoic strata (gray shading) in the Yukon Territory and Northwest Territories. (B) Detail of study area showing locations of sections studied.

accessible region in the northern Cordillera, has not previously been studied in the same detail as the Mackenzie Mountains.

The late Neoproterozoic succession of northwestern Canada, the Windermere Supergroup, was deposited during the breakup of Rodinia and the opening of the proto-Pacific (Ross, 1991; Ross et al., 1995; Dalrymple and Narbonne, 1996). Rifting likely occurred in several phases, with events at $780 \mathrm{Ma}$ (Harlan et al., 2003), 740 and $723 \mathrm{Ma}$ (geochronological constraints for deposition of basal Windermere strata reviewed by Ross et al., 1995), and $570 \mathrm{Ma}$ (Colpron et al., 2002). The top of the supergroup is the sub-Cambrian unconformity (Fig. 2). The Windermere Supergroup is up to $7 \mathrm{~km}$ thick and is exceptionally exposed in the Mackenzie Mountains and Wernecke Mountains, northwestern Canada (Fig. 1), where strata are uncleaved and only slightly metamorphosed. The basal Windermere Supergroup strata (Fig. 2) represent rift-related deposits overlain by two broad intervals of glaciogenic deposits: the Rapi$\tan$ Group, which correlates with the Sturtian tillites in Australia (Eisbacher, 1981; Young, 1992) and the Ice Brook Formation, which correlates with the Marinoan glaciation in Australia (Aitken, 1991a,b;
Sohl et al., 1999; James et al., 2001). The upper, post-rift succession of the Windermere Supergroup is siliciclastic-dominated, but contains cyclic alternations of carbonates with terrigenous clastics, referred to as Grand Cycles (Aitken, 1989). The dominantly deep-water succession of the Windermere Supergroup is well known in the Mackenzie Mountains (Aitken, 1989; Narbonne and Aitken, 1995) where it contains a superb record of Ediacaran megafossils of three distinct assemblages and an excellent chemostratigraphic record (Narbonne et al., 1994; Kaufman et al., 1997; James et al., 2001). The sedimentology and sequence stratigraphy is well understood for the Mackenzie Mountains succession (Dalrymple and Narbonne, 1996; MacNaughton et al., 2000) but the development of sequence boundaries in the deeper-water setting is muted and this hinders development of a sequence-stratigraphic framework for this succession.

Coeval, dominantly shallow-water strata in the Wernecke Mountains to the west (Fig. 1) correspond to the succession in the Mackenzie Mountains on a formation by formation basis. The Wernecke Mountains succession contains Ediacaran fossils (Narbonne and Hofmann, 1987), and carbonates that are amenable to isotope chemostratigraphy. The 


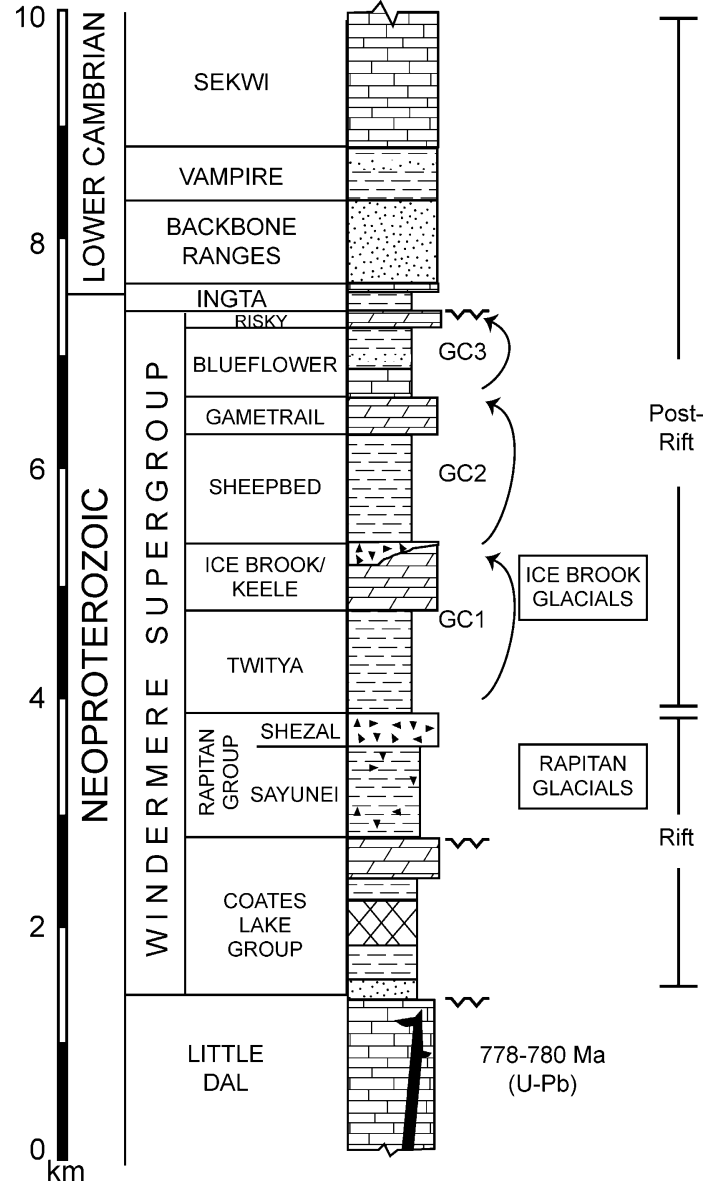

Fig. 2. Generalized stratigraphic succession in the Windermere Supergroup, Mackenzie Mountains, Northwest Territories (after Aitken, 1989; Narbonne and Aitken, 1995; Fig. 4). GC: Grand Cycle.

dominantly shallow-water setting of the Windermere Supergroup in the Wernecke Mountains provides an opportunity for a detailed stratigraphic analysis of this succession that complements the well known biostratigraphic and chemostratigraphic framework of the deeper-water Mackenzie Mountains succession. The purpose of this paper is to (1) establish the lithostratigraphic framework of the upper Windermere Supergroup in the Wernecke Mountains, (2) interpret this succession in a sequence stratigraphic context, (3) integrate the sequence stratigraphy with reconnaissance carbon isotopic data and biostratigraphic constraints for intrabasinal correlation with the Mackenzie Mountains, and (4) correlate the integrated Ediacaran chronostratigraphic record of northwestern Canada with equivalent strata globally.

\section{Windermere Supergroup}

The Windermere Supergroup extends from northwestern Canada to northern Mexico and preserves the late Precambrian rift-drift history of the Cordilleran margin of Laurentia (Ross, 1991; Ross et al., 1995). It consists of a continental-margin wedge succession that accumulated during late Neoproterozoic time on the northwestern and western margin of Laurentia and crops out along an arcuate part of the Foreland Fold and Thrust Belt of the northern Canadian Cordillera (Fig. 1A). The Windermere Supergroup in the southern Canadian Cordillera is a predominantly deep-water slope and basinal succession. The well exposed, continuous Windermere successions in the northwestern segments of the Cordillera (Mackenzie and Wernecke Mountains, Fig. 1A) are mostly shelf, shelf-edge and slope deposits and are less tectonically deformed compared to their counterparts in the south.

\subsection{Mackenzie Mountains}

The Windermere Supergroup consists of the Coates Lake Group, the Rapitan Group, and six post-Rapitan Formations (Fig. 2) that record passive continental-margin sedimentation and inception of the proto-Pacific Ocean (Dalrymple and Narbonne, 1996). The rift-drift transition is interpreted to be at the base of the siliciclastic Twitya Formation, which is the first of three, km-scale siliciclastic to carbonate Grand Cycles of the following formation pairs: Twitya-Keele, Sheepbed-Gametrail, Blueflower-Risky (Aitken, 1989, 1991a; Narbonne and Aitken, 1990, 1995) (Fig. 2). Deposition of the Twitya-Keele Grand Cycle was interrupted by a second Neoproterozoic glaciation, recorded as the Ice Brook Formation (Aitken, 1991a,b). Glacial deposits of the Ice Brook Formation and prograding cyclic shallow-water clastic-carbonate units of the underlying Keele Formation are interpreted to represent the global Marinoan glaciation and associated postglacial melting (James et al., 2001). The stratigraphic framework and depositional history of the post-Ice Brook Formation succession (Sheepbed to Risky Formations) 
is well established (Aitken, 1989, 1991a; Narbonne and Aitken, 1995; Dalrymple and Narbonne, 1996; MacNaughton et al., 2000). The top of the Windermere Supergroup is marked by a prominent unconformity and the Precambrian-Cambrian boundary occurs within the strata of the overlying Ingta Formation (Aitken, 1989; MacNaughton and Narbonne, 1999). During most of the late Neoproterozoic, the shelf trended from northwest to southeast and the shelf edge prograded southwestward from neritic environments in the eastern Mackenzies to continental slope settings in the western Mackenzies (Fig. 2 of Narbonne and Aitken, 1995; Dalrymple and Narbonne, 1996).

\subsection{Wernecke Mountains}

The upper Windermere succession is known only from preliminary lithostratigraphic studies (Aitken, 1984; Fritz et al., 1983, 1984; Narbonne et al., 1985;
Osborne et al., 1986) and a few detailed paleontological reports focused on global correlation of the Precambrian-Cambrian boundary (Hofmann, 1984; Narbonne et al., 1985; Nowlan et al., 1985). Miscorrelation by previous workers occurred because of the similarity between siliciclastic-carbonate cycles of the Sheepbed-Gametrail, Blueflower-Risky Grand Cycles and presence of additional higher-order shale-carbonate cycles. The present independent correlation based on paleontology, carbon isotope stratigraphy, sedimentology, and sequence stratigraphy establishes the lithostratigraphic framework and clarifies previous conflicting interpretations (Fig. 3). The Sheepbed, Gametrail, Blueflower and Risky Formations overlie the cap carbonate of the Ravensthroat Formation, as defined in the Mackenzie Mountains by James et al. (2001). The Blueflower Formation contains globally recognized Ediacaran megafossils (Narbonne and Hofmann, 1987). Lithostratigraphy

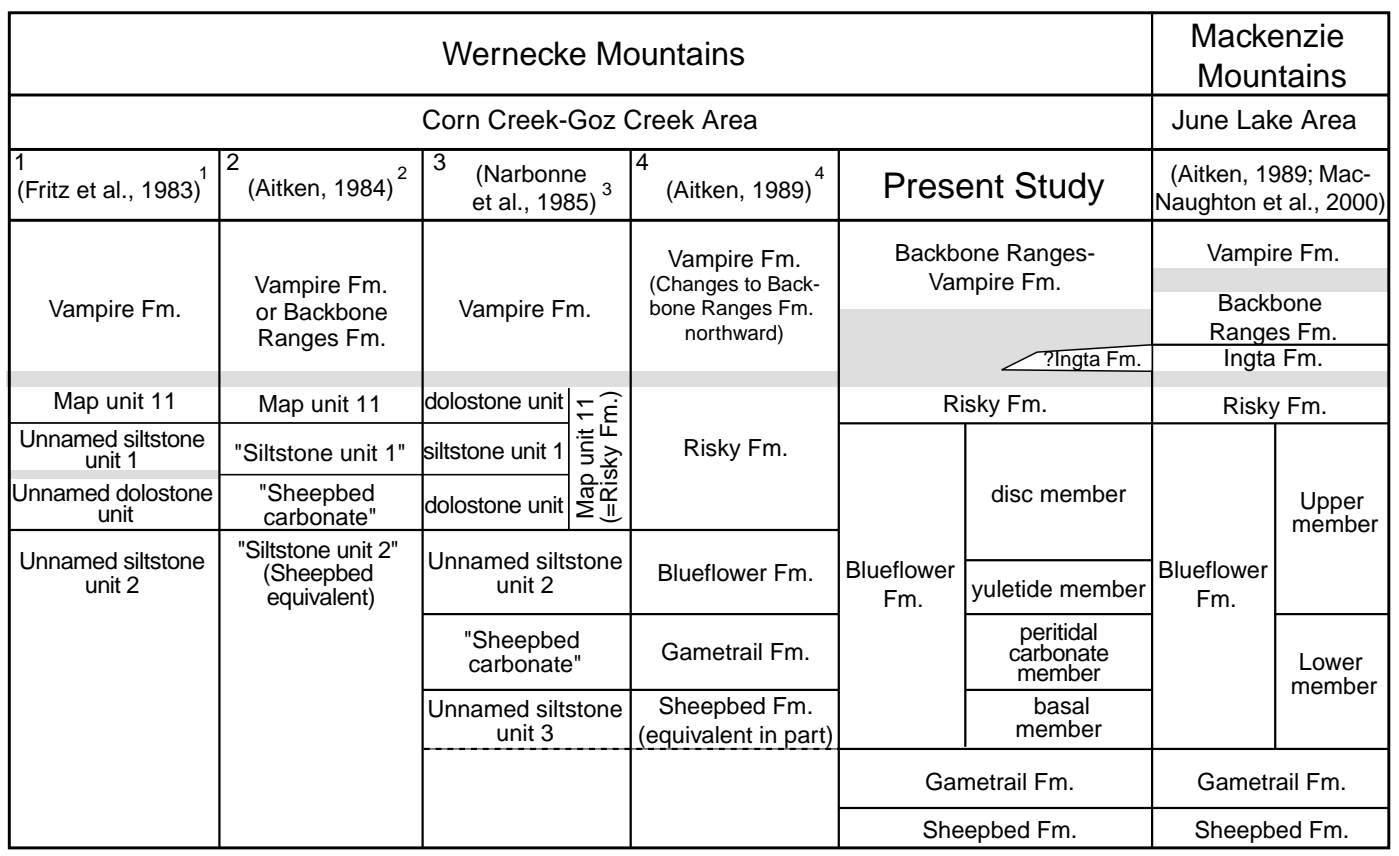

Fig. 3. Stratigraphic nomenclature and correlation of lithostratigraphic units, Wernecke Mountains and Mackenzie Mountains (unit thickness not to scale). (1) Fritz et al. (1983) based their interpretation on earlier observations at Sections B and C. (2) The interpretation by Aitken (1984) of Section A, shows an erroneous correlation of the "Sheepbed carbonate" to the unnamed dolostone; however, Aitken (1989) emended this correlation by suggesting the "Sheepbed carbonate" and "Siltstone unit 2" are equivalent to the Gametrail and Sheepbed Formations of the Mackenzie Mountains. (3) Narbonne et al. (1985) interpreted Section D1, where the correlation of units was complicated by significant facies and thickness changes. (4) The interpretation by Aitken (1989) extended formal names from the Mackenzie Mountains. 
and coarse biostratigraphic resolution indicates the succession represents post-glacial events of the terminal Proterozoic system (Ediacaran). Compared to coeval deeper water strata of the Mackenzie Mountains and southern Cordillera, the Wernecke Mountains succession differs in preserving a segment of the northwestern Laurentian passive margin dominated by a shallow-water strata with well-developed sequences.

\section{Methods}

The present research is based on fieldwork carried out at five ridge sections (A, B, C, D1 and D2; Fig. 1B), measured and described in detail across a shelf-slope transect that spans $42 \mathrm{~km}$. Sections lie within two structural panels (Nadaleen map-area, National Topographic System 106C). Sections A, B and $\mathrm{C}$ (proximal) occur within the same structural panel over a depositional length of $26 \mathrm{~km}$, which transect regional variations in facies and facies thicknesses. The southern Sections D1 and D2 (distal) record a thickening of all observed units and abrupt lateral facies changes. To determine the carbon isotopic record for the succession, reconnaissance scale sampling at Sections A and D was carried out in 1994. Carbon isotopic variations based on the reconnaissance samples are used to correlate the carbonate units across the transect and establish intrabasinal correlation to the isotopic profile of the Mackenzie Mountains succession (Narbonne et al., 1994; Kaufman et al., 1997).

\section{Geological framework}

Stratigraphic nomenclature of Ediacaran deeperwater strata in the Mackenzie Mountains is here extended to the Wernecke Mountains. The youngest pairs of formations (Sheepbed-Gametrail and Blueflower-Risky) are described in detail. Brief descriptions of the underlying Keele and Ravensthroat Formations and overlying post-Windermere Formations are included.

Fifteen facies associations (FA) (Fig. 4), nine of which are siliciclastic-dominated and six of which are carbonate-dominated, are identified based on the nature of vertical stratal relationships, unit composi- tion, grain characteristics, bedding and sedimentary structures (Table 1). Interpreted environments range from basinal to terrestrial. Eisbacher (1981, Fig. 29) proposed that the paleoslope in the Wernecke Mountains was south to southeasterly facing, a view supported by facies thickening and deepening from north to south-southeast (Fig. 4). The predominantly deep-water facies of the coeval Mackenzie Mountains succession thicken and deepen to the west and southwest. The change of structural grain and probable related change in the strike of the margin between the Mackenzie and Wernecke Mountains, approximately north-south and east-west, respectively, suggest an arcuate margin (Eisbacher, 1985).

\subsection{Keele and Ravensthroat Formations}

The Keele and Ravensthroat Formations were not examined in detail but both are prominent marker beds. The Keele Formation, up to $600 \mathrm{~m}$ thick in the Mackenzie Mountains (Gabrielse et al., 1973), is a complex of platform carbonate and overlying orange-red-weathering pebbly quartzite (= "Keele Clastic Wedge"; Narbonne and Aitken, 1995). In the Wernecke Mountains, the Keele Formation is only up to $40 \mathrm{~m}$ thick and is composed of shallow shelf to fluvial siliciclastics probably equivalent to the Keele Clastic Wedge. Yellow-weathering, finely crystalline dolostone and rare limestone (23 m thick; Figs. 4 and 5A) overlie the Keele Formation (Eisbacher, 1981, 1985) and are referred to the Ravensthroat Formatioan (= Ice Brook cap carbonate) described by James et al. (2001) in equivalent strata of the Mackenzie Mountains. The Ice Brook cap carbonate has attributes similar to coeval Marinoan caps globally including laminated peloidal sediments, corrugated stromatolites, and synsedimentary tepee-like structures (James et al., 2001). The cap carbonate is overlain abruptly and conformably by black shale of the Sheepbed Formation (Figs. 4 and 5A).

\subsection{Sheepbed Formation}

In the Mackenzie Mountains, the Sheepbed Formation (Gabrielse et al., 1973) represents deposition on a passive-margin continental slope (Dalrymple and Narbonne, 1996). A slope setting is also interpreted for the lithologically similar Sheepbed Formation in the 
PROXIMAL

DISTAL

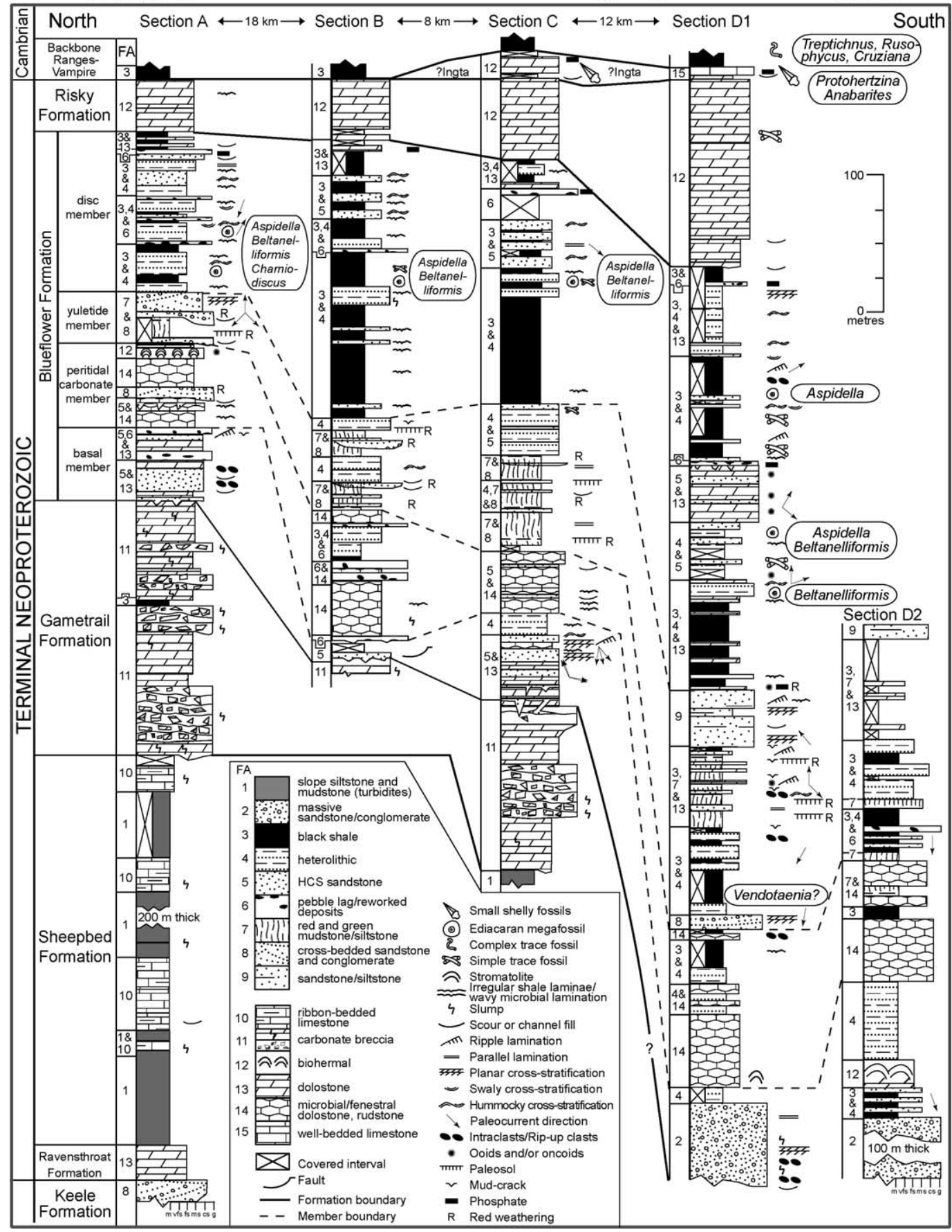

Fig. 4. Measured Sections A, B, C, D1 and D2 showing the lithostratigraphic correlation across the transect. Datum is the unconformity at the top of the Risky Formation that approximates the Precambrian-Cambrian boundary in the absence of the overlying Ingta Formation. Stratigraphic levels of fossil occurrences based on the present study and reported occurrences from Hofmann et al. (1983) Nowlan et al. (1985) and Narbonne and Hofmann (1987). 
Table 1

Summary of facies and facies associations

\begin{tabular}{|c|c|c|c|c|}
\hline \multicolumn{2}{|l|}{ FA } & \multirow[t]{2}{*}{ Unit description } & \multirow[t]{2}{*}{$\begin{array}{l}\text { Grain size, bedding } \\
\text { and structures }\end{array}$} & \multirow[t]{2}{*}{ Interpretation } \\
\hline Clastic & ninated & & & \\
\hline 1 & $\begin{array}{l}\text { Laminated siltstone } \\
\text { and mudstone, shale }\end{array}$ & $\begin{array}{l}\text { Uniform shale and mudstone } \\
\text { with laminated siltstone } \\
\text { beds; units up to } 60 \mathrm{~m} \text { thick }\end{array}$ & $\begin{array}{l}\text { Turbidites: medium to } \\
\text { coarse silt and mud } \\
\text { Background: mud } \\
\text { Bedding indeterminate to } \\
\text { thin } \\
\mathrm{T}_{(\mathrm{D}) \mathrm{E}} \text { : finely laminated } \\
\text { silt and mud; rare slumps } \\
\text { in resistant siltstone beds }\end{array}$ & $\begin{array}{l}\text { Continental slope; deposition } \\
\text { by turbidity currents, } \\
\text { slumping, and hemipelagic } \\
\text { settling }\end{array}$ \\
\hline 2 & $\begin{array}{l}\text { Massive sandstone } \\
\text { and conglomerate }\end{array}$ & $\begin{array}{l}\text { Channel deposits; massive } \\
\text { units with mudstone and } \\
\text { siltstone interbeds ( } 20 \mathrm{~cm} \text { to } \\
3 \mathrm{~m} \text { thick); units } 20-30 \mathrm{~cm} \\
\text { to } 100 \mathrm{~m} \text { thick, thin to } 0 \mathrm{~m} \\
\text { laterally }\end{array}$ & $\begin{array}{l}\text { Coarse sand to } \\
\text { pebble-granule; fine silt } \\
\text { Thin bedded to massive } \\
\text { Rare cross-beds of } \\
\text { granules with rare } \\
\text { sandstone } \\
\text { In siltstone and } \\
\text { mudstone: truncations } \\
\text { and slump scars and } \\
\text { folds; shale rip-up clasts; } \\
\text { fine lamination; lack of } \\
\text { wave or current } \\
\text { structures; no grading }\end{array}$ & $\begin{array}{l}\text { Continental slope near } \\
\text { shelfbreak; rapid } \\
\text { sedimentation, submarine } \\
\text { channel fill; background } \\
\text { sedimentation contour } \\
\text { currents and/or suspension }\end{array}$ \\
\hline 3 & Black shale & $\begin{array}{l}\text { Wavy laminated, drapes } \\
\text { sandstone beds and } \\
\text { comprises interbeds of FA } 5 \text {, } \\
\text { pyritic; units } 1-10 \text { m thick }\end{array}$ & $\begin{array}{l}\text { Mud to fine silt } \\
\mathrm{mm} \text {-scale laminae to } \\
2 \mathrm{~cm} \text { beds } \\
\text { Forms mud drapes, } \\
\text { fissile, pyritic, absence of } \\
\text { wave structures }\end{array}$ & $\begin{array}{l}\text { Deep subtidal shelf; muddy, } \\
\text { low energy, below storm } \\
\text { wave base }\end{array}$ \\
\hline 4 & Heterolithic & $\begin{array}{l}\text { Sandstone, siltstone and } \\
\text { shale beds, fining upward; } \\
\text { interbedded with FA } 3 \text {; units } \\
1-10 \text { m thick }\end{array}$ & $\begin{array}{l}\text { Fine to coarse sand, fine } \\
\text { to medium silt } \\
\text { Thin to thick bedded, } \\
\text { scoured bed bases } \\
\text { HCS, gutter casts, } \\
\text { cross-lamination and } \\
\text { tabular cross-bedding; } \\
\text { soft-sedimentary } \\
\text { deformation; shale clasts; } \\
\text { wave ripples and mud } \\
\text { drapes, syneresis cracks } \\
\text { Ediacaran fossils, trace } \\
\text { fossils }\end{array}$ & $\begin{array}{l}\text { Clastic shelf; high energy, } \\
\text { below fair-weather wave } \\
\text { base, above storm wave base }\end{array}$ \\
\hline 5 & HCS sandstone & $\begin{array}{l}\text { Quartz sandstone and } \\
\text { dolomitic quartz sandstone, } \\
\text { weather white and orange; } \\
\text { interbedded with FA 13; }\end{array}$ & $\begin{array}{l}\text { Fine to medium sand; } \\
\text { microcrystalline } \\
\text { quartzose dolostone; rare } \\
\text { stromatolitic clasts }\end{array}$ & $\begin{array}{l}\text { Shallow mixed } \\
\text { carbonate-clastic shelf and } \\
\text { shoreface; deposition by } \\
\text { storm waves }\end{array}$ \\
\hline
\end{tabular}


Table 1 (Continued)

\begin{tabular}{|c|c|c|c|c|}
\hline \multirow[t]{2}{*}{ FA } & & \multirow[t]{2}{*}{ Unit description } & $\begin{array}{l}\text { Grain size, bedding } \\
\text { and structures }\end{array}$ & \multirow[t]{2}{*}{ Interpretation } \\
\hline & & & $\begin{array}{l}\text { Thin to thick bedded } \\
\text { HCS, SCS and dcm-scale } \\
\text { planar cross-bedding; some } \\
\text { planar lamination; load } \\
\text { structures; convolute } \\
\text { bedding; wavy microbial } \\
\text { lamination }\end{array}$ & \\
\hline 6 & $\begin{array}{l}\text { Pebble lag or } \\
\text { reworked deposit }\end{array}$ & $\begin{array}{l}\text { Beds of variable lithologies, } \\
\text { commonly containing } \\
\text { phosphatic pebbles or rip-up } \\
\text { clasts; units } 1-7 \mathrm{~m} \text { thick }\end{array}$ & $\begin{array}{l}\text { Dolostone or phosphate } \\
\text { pebbles } 5 \mathrm{~cm} \text { long; mud } \\
\text { chip rip-up clasts; clasts } \\
\text { Tingnlaw thickuheldded } \\
\text { Sharp, scoured bed bases }\end{array}$ & $\begin{array}{l}\text { Shallow shelf to shoreface; } \\
\text { high energy, mechanical } \\
\text { concentration and/or } \\
\text { reworking }\end{array}$ \\
\hline 7 & $\begin{array}{l}\text { Red and green } \\
\text { mudstone/siltstone }\end{array}$ & $\begin{array}{l}\text { Red, yellow-green } \\
\text { weathering, brown staining, } \\
\text { friable, non-fissile, brecciated } \\
\text { mudstone, siltstone, shale } \\
\text { horizons; nodular or } \\
\text { subangular blocky; cyclically } \\
\text { interbedded with FA 14; } \\
\text { units }<0.5-23 \mathrm{~m} \text { thick }\end{array}$ & $\begin{array}{l}\text { Mud to fine silt, minor sand } \\
\text { Thin bedded, nodules } \\
2-10 \mathrm{~cm} \text { long with clay } \\
\text { "skin"; irregular bedding } \\
\text { surfaces; brecciated, rare } \\
\text { intervals of remnant } \\
\text { cross-beds sets, desiccation } \\
\text { cracks; dolomitic } \\
\text { concretions; finely, planar } \\
\text { to irregularly laminated; } \\
\text { possible rain-drop imprints }\end{array}$ & $\begin{array}{l}\text { Terrestrial floodplain; } \\
\text { pedogenic development } \\
\text { during subaerial exposure } \\
\text { and wetting/drying phases }\end{array}$ \\
\hline 8 & $\begin{array}{l}\text { Cross-bedded } \\
\text { sandstone and } \\
\text { conglomerate }\end{array}$ & $\begin{array}{l}\text { Red weathering, fining } \\
\text { upwards from conglomeratic } \\
\text { base, variegated shale } \\
\text { interbeds; discontinous beds } \\
\text { in units } 0.5-20 \mathrm{~m} \text { thick }\end{array}$ & $\begin{array}{l}\text { Coarse sand to pebbles, } \\
\text { polymictic clasts } \\
\text { Beds thin and laterally } \\
\text { discontinuous } \\
\text { Cross-bedded, } \\
\text { paleocurrents diverse } \\
\text { between packages; medium } \\
\text { sandstone caps of clean, } \\
\text { white quartzite (FA 5) }\end{array}$ & Fluvial; channel deposits \\
\hline 9 & Sandstone/siltstone & $\begin{array}{l}\text { Red-brown weathering } \\
\text { sandstone and laminated, } \\
\text { gray siltstone interbeds with } \\
\text { sandstone lenses, drapes and } \\
\text { interbeds of pyritic black } \\
\text { shale; units } 1-20 \mathrm{~m} \text { thick }\end{array}$ & $\begin{array}{l}\text { Medium to coarse sand, } \\
\text { well rounded and sorted; } \\
\text { fine silt } \\
\text { Thin to thick bedded; sand } \\
\text { lenses within finely } \\
\text { laminated, pyritic, siltstone } \\
\text { beds, shale partings } \\
\text { Starved ripples and } \\
\text { microbial laminae; flat } \\
\text { laminae, rare cross-bedding } \\
\text { (diverse paleocurrents); } \\
\text { loaded bed bases, mud } \\
\text { flasers drape ripples; fining } \\
\text { upwards successions, } \\
\text { syneresis cracks }\end{array}$ & $\begin{array}{l}\text { Coastal to estuarine/lagoonal; } \\
\text { clastic dominated with } \\
\text { episodic tidal flow }\end{array}$ \\
\hline
\end{tabular}




\begin{tabular}{|c|c|c|c|c|}
\hline \multicolumn{2}{|l|}{ FA } & \multirow[t]{2}{*}{ Unit description } & \multirow[t]{2}{*}{$\begin{array}{l}\text { Grain size, bedding } \\
\text { and structures }\end{array}$} & \multirow[t]{2}{*}{ Interpretation } \\
\hline Carbo & dominated & & & \\
\hline 10 & $\begin{array}{l}\text { Ribbon-bedded } \\
\text { limestone }\end{array}$ & $\begin{array}{l}\text { Interbedded lime mudstone, } \\
\text { mudstone and clastic shale } \\
\text { (FA 2), parted to ribbon } \\
\text { bedded and/or nodular; units } \\
7-18 \mathrm{~m} \text { thick }\end{array}$ & $\begin{array}{l}\text { Lime mudstone to } \\
\text { wackestone, calcareous } \\
\text { shale; mudstone: mud to silt } \\
\text { Beds thin to medium, } \\
\text { lenses } 8-10 \mathrm{~cm} \text { thick; } \\
\text { mudstone: }<1-10 \mathrm{~cm} \\
\text { Soft sedimentary } \\
\text { deformation; bed bases } \\
\text { sharp and erosive; some } \\
\text { normal grading; vague } \\
\text { lamination; small slump } \\
\text { folds }\end{array}$ & $\begin{array}{l}\text { Continental slope; } \\
\text { deposition by turbidity } \\
\text { currents and hemipelagic } \\
\text { settling }\end{array}$ \\
\hline 11 & Carbonate breccia & $\begin{array}{l}\text { Intraformational dolomitized } \\
\text { breccia and slope carbonate; } \\
\text { units } 2-37 \mathrm{~m} \text { thick, with } \mathrm{cm} \\
\text { to dcm scale downcutting }\end{array}$ & $\begin{array}{l}\text { Pebbles to boulders (some } \\
\text { several } \mathrm{m} \text { in size) of } \\
\text { laminated shelf dolostone } \\
\text { Thick bedded to massive } \\
\text { Matrix supported, } \\
\text { asymmetric slump folds } \\
\text { with } 0.5-3 \mathrm{~m} \text { amplitude, } \\
\text { bed bases scoured, sharp } \\
\text { and erosive; truncated } \\
\text { beds; slumped, microbially } \\
\text { laminated interbeds }\end{array}$ & $\begin{array}{l}\text { Carbonate slope; deposition } \\
\text { by shelf-derived debris } \\
\text { flows }\end{array}$ \\
\hline 12 & Biohermal & $\begin{array}{l}\text { Complex of stromatolitic, } \\
\text { thrombolitic and microbially } \\
\text { laminated dolostone; upper } \\
\text { dome with } 12 \mathrm{~m} \text { relief; unit } \\
20 \mathrm{~m} \text { thick }\end{array}$ & $\begin{array}{l}\text { Fine crystalline, } \\
\text { dolomudstone to } \\
\text { framestone } \\
\text { Thin bedded to massive } \\
\text { Broad and open oblate } \\
\text { domal stromatolites, } \\
\text { dcm-scale, laterally-linked } \\
\text { hemispheric style, cm-scale } \\
\text { columns; clotted textures } \\
\text { and laminated microbial } \\
\text { fabrics; finely laminated } \\
\text { dolomudstone }\end{array}$ & Shallow subtidal shelf \\
\hline 13 & Dolostone & $\begin{array}{l}\text { Dolostone, sandy dolostone } \\
\text { and oolite; peach to gray } \\
\text { weathering; units } 1-45 \mathrm{~m} \\
\text { thick }\end{array}$ & $\begin{array}{l}\text { Fine to medium crystalline, } \\
\text { sucrosic; medium sand } \\
\text { sized to granule ooids; } \\
\text { oncoids; coarse quartz sand } \\
\text { Thin to thick bedded, } \\
\text { locally erosional bed bases } \\
\text { Low angle planar } \\
\text { cross-bedding in } 0.1-0.2 \mathrm{~m} \\
\text { thick sets; minor } \\
\text { herringbone cross-bedding; } \\
\text { grading from ooids to } \\
\text { pisoids in sets } 2 \text { m thick; } \\
\text { HCS, SCS } \\
\text { Few original fabrics, cryptic } \\
\text { to vaguely or microbially } \\
\text { laminated; locally vuggy }\end{array}$ & $\begin{array}{l}\text { Shallow carbonate to mixed } \\
\text { clastic-carbonate shelf and } \\
\text { shoal; high energy with } \\
\text { storm wave influence }\end{array}$ \\
\hline
\end{tabular}


Table 1 (Continued)

\begin{tabular}{|c|c|c|c|c|}
\hline \multicolumn{2}{|l|}{ FA } & \multirow{2}{*}{$\begin{array}{l}\text { Unit description } \\
\text { Complex of intraclastic } \\
\text { and stromaclastic } \\
\text { rudstone, dolograinstone, } \\
\text { stromatolitic dolostone, } \\
\text { microbially laminated } \\
\text { dolostone; units } 20 \mathrm{~cm} \text { to } \\
20 \mathrm{~m} \text { thick }\end{array}$} & \multirow[b]{2}{*}{$\begin{array}{l}\text { Grain size, bedding } \\
\text { and structures } \\
\text { Microcrystalline } \\
\text { dolomite, packstone, } \\
\text { grainstone, rudstone; } \\
\text { tabular clasts } 1-2 \mathrm{~cm} \\
\text { Thin bedded; } \\
\text { stromatolites with } \\
10-50 \mathrm{~cm} \text { relief } \\
\text { Cross-bedded in } \\
10-20 \mathrm{~cm} \text { sets, } \\
\text { herringbone imbrication } \\
\text { of clasts, small tepees, } \\
\text { oncoid-pisoid sized } \\
\text { vugs, several stages of } \\
\text { dolomite cement; } \\
\text { desiccation cracks, } \\
\text { small fenestrae, highly } \\
\text { stylolized }\end{array}$} & Interpretation \\
\hline 14 & $\begin{array}{l}\text { Microbial/fenestral } \\
\text { dolostone, rudstone }\end{array}$ & & & $\begin{array}{l}\text { Shallow subtidal to } \\
\text { supratidal; influence } \\
\text { of storm waves }\end{array}$ \\
\hline \multirow[t]{2}{*}{15} & $\begin{array}{l}\text { Well-bedded } \\
\text { limestone }\end{array}$ & $\begin{array}{l}\text { Limestone, locally } \\
\text { dolomitized; unit } 9 \mathrm{~m} \\
\text { thick }\end{array}$ & $\begin{array}{l}\text { Lime mudstone, } \\
\text { wackestone, grainstone } \\
\text { to rudstone (rip-up } \\
\text { clasts and stromatolites } \\
2-6 \mathrm{~cm} \text { long) }\end{array}$ & $\begin{array}{l}\text { Mid-outer shelf; } \\
\text { penecontemporaneous } \\
\text { storm reworking }\end{array}$ \\
\hline & & & $\begin{array}{l}\text { Thin bedded, bed bases } \\
\text { scoured, tops sharp; } \\
\text { soft-sedimentary } \\
\text { deformation; } \\
\text { dolomitized with } \\
\text { compaction rotation in } \\
\text { basal } 4 \mathrm{~m} \text {; complex } \\
\text { diagenesis and } \\
\text { phosphatization in } \\
\text { upper } 1 \mathrm{~m} \\
\text { Rosettes and tepees in } \\
\text { upper } 1 \mathrm{~m} \text {; current } \\
\text { ripples }\end{array}$ & \\
\hline
\end{tabular}

Wernecke Mountains (Table 2). The most continuous section of Sheepbed Formation is present at Section A (446 m thick, Figs. 4 and 5A).

\subsection{Gametrail Formation}

In the Mackenzie Mountains, the Gametrail Formation ( $320 \mathrm{~m}$ thick) is represented by coarse-grained platformal carbonates in the northeast and ribbonbedded limestones and carbonate debrites in the slope facies to the southwest. It has an interbedded and gradational contact with the underlying Sheepbed Formation. In the Wernecke Mountains, the Gametrail Formation is a light gray-weathering, resistant, cliff-forming carbonate unit (124-186.7 m thick) that overlies the Sheepbed Formation (Fig. 5A and B). The dominant lithology of the formation is carbonate debrites (Table 2). The chaotic nature of the units, presence of asymmetric slump folds (Fig. 6B), and bed truncation are consistent with deposition by debris flows on a carbonate slope (Coniglio and Dix, 1992). 

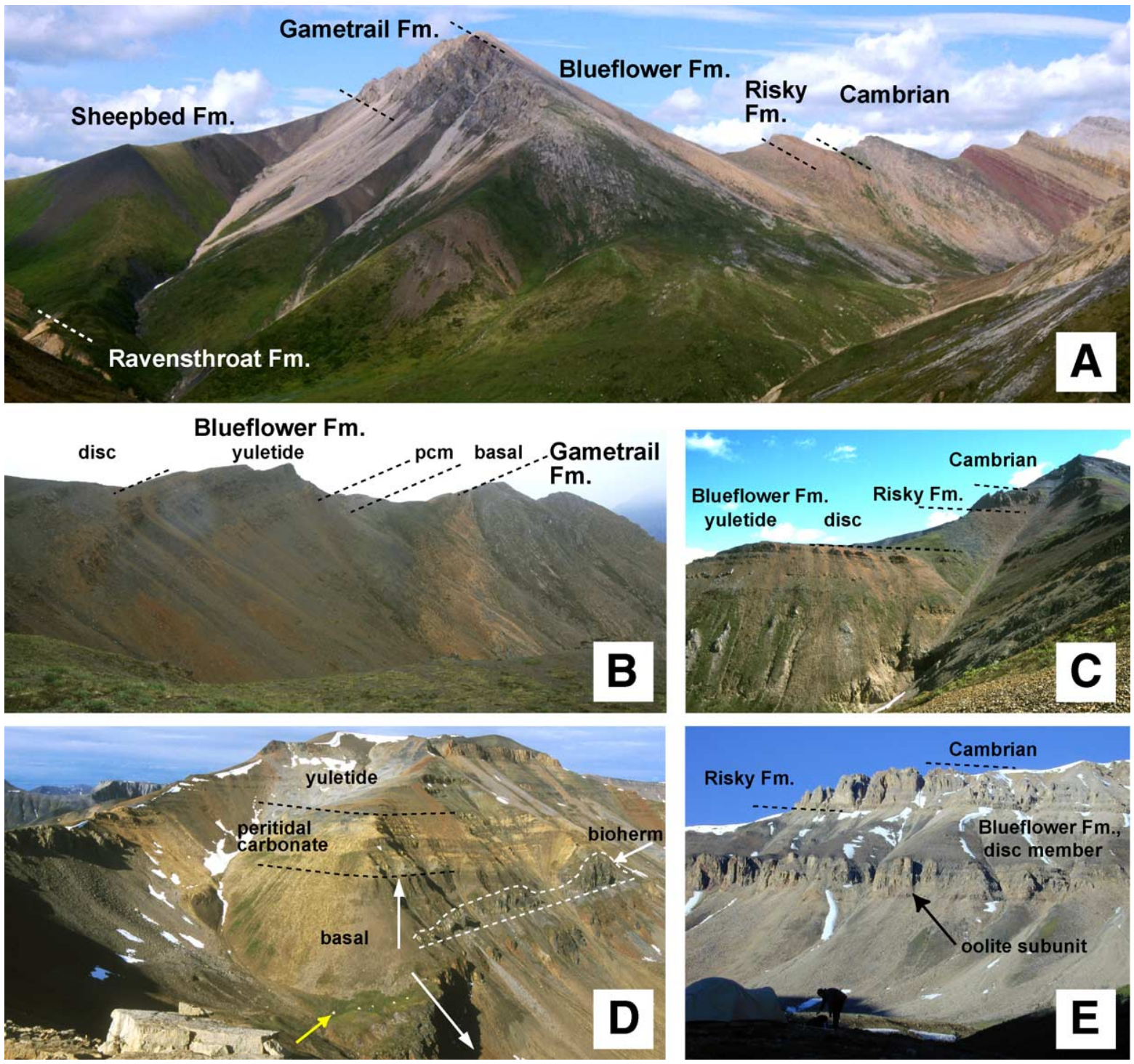

Fig. 5. Field photographs of the upper Windermere Supergroup. (A) View of Section A to the northeast, ca. $1 \mathrm{~km}$ thick from Ravensthroat Formation to the top of the Risky Formation. (B) View of Section C to the west, showing thickening of members of the Blueflower Formation compared to Section A (basal, pcm = peritidal carbonate, yuletide and disc members). (C) View of the same ridge as (B) but to the east, showing continuation of the section up to the Cambrian strata. (D) View of Section D2 to the southwest, showing the great thickening of the Blueflower Formation and remarkable facies changes. Camp (at yellow arrow) sits on $100 \mathrm{~m}$ thick submarine channel conglomerate, overlain by shelf sands and a spectacular bioherm (outlined) comprising the basal member. The peritidal carbonate member is overlain by the red-weathering yuletide member that consists of several paleosol horizons. (E) View of the upper part of Section D1 to the southwest, consisting of the upper Blueflower Formation (disc member) that contains a carbonate subunit of oolite and shoreface sandstone overlain by recessive shallow shelf deposits. The Risky Formation forms the upper part of the cliff and is overlain by Cambrian strata. 
Table 2

Summary of formations (FA from Table 1)

\begin{tabular}{|c|c|c|c|}
\hline \multirow[t]{2}{*}{ Formation/member } & \multirow[t]{2}{*}{ FA } & \multicolumn{2}{|l|}{ Description and depositional environment } \\
\hline & & Wernecke Mountains & Mackenzie Mountains \\
\hline Ingta & 15 & $\begin{array}{l}\text { Thin bedded limestone, minor dolostone } \\
\text { partings; rudstone, grainstone rip-up clasts, } \\
\text { phosphatization in upper } 1 \mathrm{~m} \\
\text { Up to } 14 \mathrm{~m} \text { thick } \\
\text { Mid- to outer-shelf }\end{array}$ & $\begin{array}{l}\text { Ingta Formation (shale, sandstone, } \\
\text { limestone) lies between Risky and } \\
\text { Backbone Ranges formations } \\
\text { Variable thickness, up to } 256 \mathrm{~m} \\
\text { Siliciclastic and carbonate shelf }\end{array}$ \\
\hline Risky & 13 & $\begin{array}{l}\text { Dolostone with few preserved textures } \\
\text { (oolite, microbial lamination, cross-bedding) } \\
\text { Thickens from } 26 \text { to } 136.5 \mathrm{~m} \text { southward } \\
\text { Carbonate, mixed siliciclastic-carbonate } \\
\text { shelf }\end{array}$ & $\begin{array}{l}\text { Oolite, oncoid wackestone/floatstone, } \\
\text { stromatolites, dolomitic sandstone, sandy } \\
\text { dolomite } \\
\text { Up to } 167 \mathrm{~m} \text { thick } \\
\text { Carbonate, mixed siliciclastic-carbonate } \\
\text { shelf }\end{array}$ \\
\hline \multicolumn{4}{|l|}{ Blueflower } \\
\hline Disc member & $3,4,5,6$ and 13 & $\begin{array}{l}\text { Recessive, homogeneous unit of black } \\
\text { shale, HCS sandstone, white quartzite, } \\
\text { minor dolostone; carbonate-dominated } \\
\text { (oolite) interval distally }\end{array}$ & $\begin{array}{l}\text { Upper part: siliciclastic dominated } \\
\text { turbidites, carbonate olistoliths, shoreface } \\
\text { sandstone at the top of the unit Up to } 290 \\
\mathrm{~m} \text { thick Continental slope (carbonate and } \\
\text { siliciclastic) and shoreface }\end{array}$ \\
\hline
\end{tabular}

Yuletide member

Peritidal carbonate member

Basal member
$3,4,7,8$ and 9

14

$2,3,4,5,6,12$ and 13

11
Thickens southward from 114 to $305 \mathrm{~m}$ Shallow shelf and carbonate shoal

Thin bedded and nodular, non-fissile red and green siltstone and mudstone, calcitic nodules, paleosols; upper part dominated by shale and sandstone; distally contains coastal sandstone and shale Thickens southward from 40 to $180 \mathrm{~m}$ Terrestrial, coastal and shallow marine

Microbial/fenestral dolostone, rudstone, dolograinstone, stromatolitic dolostone, sandy dolostone

Thickens southward from 45 to $117 \mathrm{~m}$ Subtidal (muddy carbonate tidal flat) to supratidal

Distally: coarse submarine channel fills, fine siliciclastics (muddy shelf to transitional facies), microbial pinnacle bioherms up to $12 \mathrm{~m}$ thick; Proximally: sandstone, lag deposits and rare dolostone beds Thickens southward from 50 to $200 \mathrm{~m}$ Slope to shallow shelf

Polymict, pebble-sized, matrix-supported, carbonate debrites; shelf-derived clasts of laminated dolostone in debrites; interbeds of cryptic, structureless dolostone and laminated, slumped dolostone

At least $187 \mathrm{~m}$ thick

Carbonate slope
Contact with Gametrail Formation gradational Continental slope (carbonate-dominated)

Lower part: parted slope limestone, sandy limestone

Up to $280 \mathrm{~m}$ thick

Contact with Gametrail Formation gradational

Continental slope (carbonate-dominated)

Platformal carbonates in northeast and slope carbonates in southwest

Up to $320 \mathrm{~m}$ thick

Carbonate platform to slope 
Table 2 (Continued)

\begin{tabular}{llll}
\hline Formation/member & FA & Description and depositional environment & \\
\cline { 3 - 4 } & & Wernecke Mountains & Mackenzie Mountains \\
\hline Sheepbed & 1 and 10 & $\begin{array}{l}\text { Silt-dominated, finely laminated distal } \\
\text { turbidites with rare slump folding and } \\
\text { ribbon-bedded limestone }\end{array}$ & Fine-grained siliciclastics, shale-dominated \\
& & $\begin{array}{l}\text { At least } 446 \mathrm{~m} \text { thick } \\
\text { Siliciclastic-dominated to carbonate slope }\end{array}$ & $\begin{array}{l}\text { Up to } 1.5 \mathrm{~km} \text { thick } \\
\text { Siliciclastic-dominated passive-margin slope }\end{array}$ \\
& &
\end{tabular}

\subsection{Blueflower Formation}

In the Mackenzie Mountains, the Blueflower Formation (1000 m thick) consists of submarine channel fills and slumps and debrites consistent with a slope setting (Aitken, 1989). MacNaughton et al. (2000) divided the Blueflower into a lower part consisting of deep-water carbonates and an upper part consisting of deep-water turbidites and carbonate olistoliths that pass upward into shoreface sandstones (MacNaughton et al., 2000). In the Wernecke Mountains, the Blueflower Formation is a mixed siliciclastic and carbonate succession that likewise lies between the Gametrail and Risky Formations, although the shallow-water facies are quite different from their deeper water equivalents in the Mackenzie Mountains (Table 2). Correlation is supported by the concentration of carbonates in the lower part and dominance of siliciclastics in the upper part as well as correlation of sequence boundaries (as discussed below). The Blueflower Formation is more than $600 \mathrm{~m}$ thick at southern sections and thins northward to $266 \mathrm{~m}$. It is herein subdivided into four informal members that represent distinct, mappable units (Table 2; Figs. 3, 4 and 5B-E).

The basal member (50-200 m thick) consists of coarse submarine channel fills, fine siliciclastics (Fig. 6C), and microbial pinnacle reef mounds (Fig. 5D) that mark the transition from deep-water slope to shallow shelf conditions (Fig. 4, Table 2). The peritidal carbonate member ( $45-117 \mathrm{~m}$ thick) is lithologically variable, dominated by a complex of peritidal facies (Table 1) with interbeds of marine and terrestrial siliciclastics (Figs. 5D and 6D). The yuletide member $(40-180 \mathrm{~m}$ thick) is a prominent marker unit named for its characteristic friable, red-maroon and bright apple green-weathering interpreted terrestrial deposits (Fig. 6F) and fluvial sandstone and conglomerate (Fig. 6E). The uppermost member of the Blueflower Formation is called the disc member (114-305 $\mathrm{m}$ thick) because it contains disc-shaped fossils of the Ediacaran biota along with carbonaceous discs of uncertain affinities. It contains black shale interbedded with orange-weathering HCS sandstone beds and an increasing number of thicker, well cemented, white-weathering quartzite units in the upper part of the unit (Fig. 4, Table 2). Near the middle of the disc member in the most distal section, a carbonate-dominated unit containing granule-sized giant ooids occurs (Fig. 6G).

\subsection{Risky Formation}

In the Mackenzie Mountains, the Risky Formation (Aitken, 1989) is a resistant unit (up to $167 \mathrm{~m}$ thick) of rose- to peach-weathering, cliff-forming, platform carbonate interbedded with dolomitic sandstone and sandy dolomite. The base of the formation is gradational with the underlying Blueflower Formation, and the top is a karstic unconformity below uppermost Neoproterozoic to basal Cambrian shallow-marine to nonmarine deposits (MacNaughton et al., 1997, 2000).

In the Wernecke Mountains, the Risky Formation is a distinctive, cliff-forming, blocky weathering, locally quartzose, orange to rose weathering dolostone (Fig. 5A, C and E). Dolomitization was fabric-destructive but there are a few preserved textures such as oolite, microbial lamination and cross-bedding (FA 13). The Risky Formation thins, or more likely is truncated, from $136.5 \mathrm{~m}$ in the south to $26 \mathrm{~m}$ in the north (Fig. 4). The upper boundary is cavernous with Mississippi Valley type zinc and lead mineralization (Osborne et al., 1986) and with the uppermost $1.5 \mathrm{~m}$ containing an extensive fracture system lined with phosphate and filled with phosphatic clasts. This discontinuity is regional in extent and is 

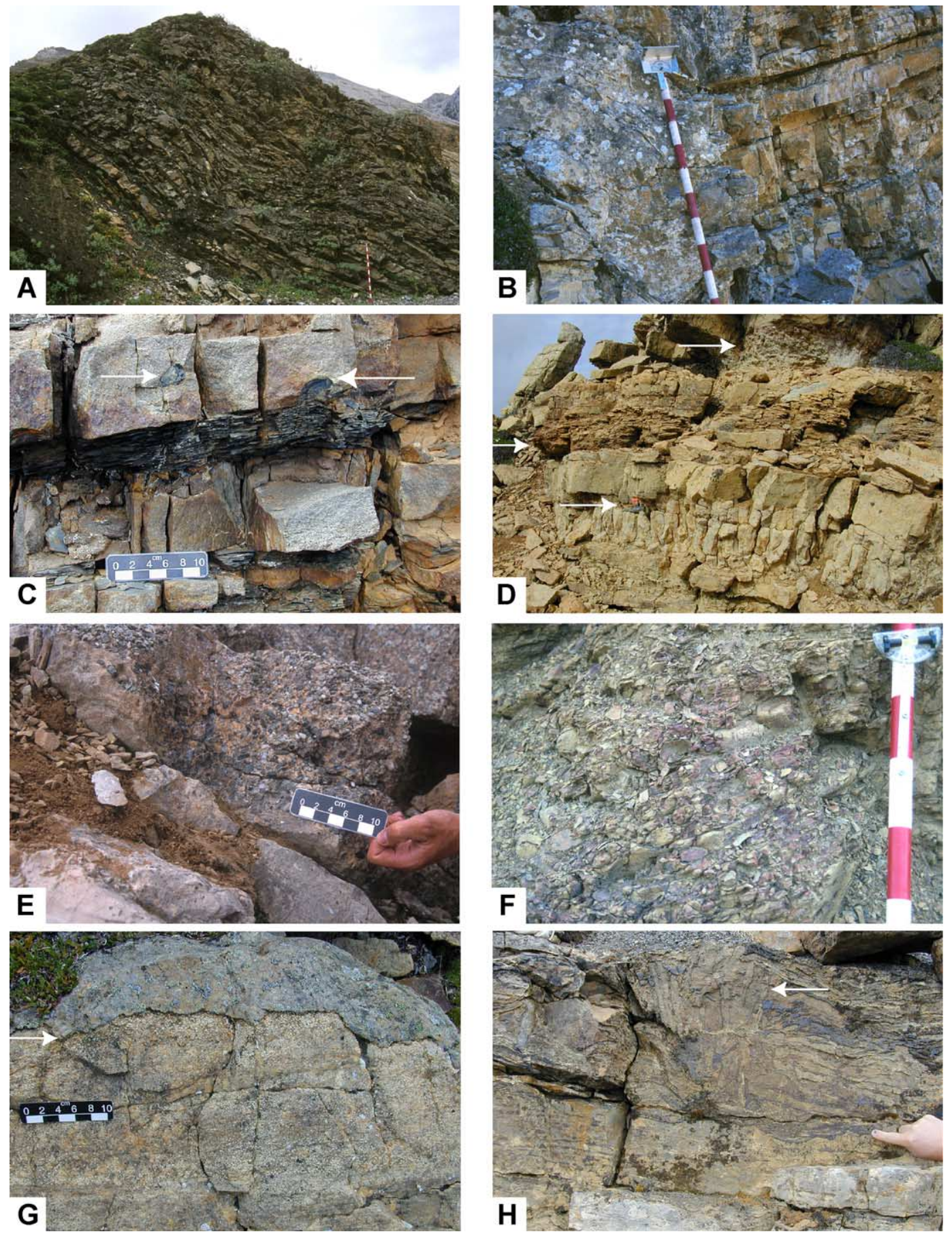
referred to as the "sub-Cambrian" unconformity (e.g., Narbonne and Aitken, 1995).

\subsection{Post-Windermere Formations}

In the Mackenzie Mountains, the Ingta (Table 2) and Vampire Formations are siliciclastic-dominated strata regarded as post-Windermere in age because of the regional karstic unconformity at the top of the Risky Formation and the occurrence of Cambrian small shelly fossils and trace fossils high in the Ingta Formation (MacNaughton and Narbonne, 1999). In the Wernecke Mountains, a limestone and dolostone unit (FA 15, Table 1), 9-14 m thick, is here questionably assigned to the Ingta Formation (Fig. 5C and E). It is present above the Risky Formation at Sections $\mathrm{C}$ and $\mathrm{D} 1$ is overlain by black shale assigned to the Backbone Ranges-Vampire Formation (Fig. 3). Within the upper part of the unit, extensive phosphatization occurs in the form of hardgrounds, intraclasts and cement between carbonate clasts (Fig. 6H) and abundant quartz sand implies a siliciclastic shoreface landward. Osborne et al. (1986) and Nowlan et al. (1985) referred to this phosphatic limestone unit as a basal unit of the Vampire Formation before the Ingta Formation was named formally.

\section{Biostratigraphy}

\subsection{Mackenzie Mountains}

There are no radiometric dates available for the upper part of the Windermere Supergroup in the northwestern Cordillera. Simple discs of Ediacaran aspect occur in the Twitya Formation (Hofmann et al., 1990). More complex Ediacaran fossils occur in the
Sheepbed and Blueflower Formations, and simple trace fossils occur in the Gametrail, Blueflower, and Risky Formations (Hofmann, 1981; Aitken, 1989; Narbonne and Aitken, 1990, 1995; Narbonne et al., 1994; MacNaughton et al., 2000). The base of the Cambrian lies high in the Ingta Formation at the base of the Treptichnus pedum biozone (MacNaughton and Narbonne, 1999) and near the first appearance of the small shelly fossil Protohertzina (Conway Morris and Fritz, 1980).

\subsection{Wernecke Mountains}

A terminal Proterozoic age is indicated by: (1) the occurrence of Ediacaran fossils and simple trace fossils in the Blueflower Formation (Hofmann et al., 1983; Narbonne and Hofmann, 1987); (2) the assemblage of small shelly fossils of Early Cambrian age in the Ingta Formation (Nowlan et al., 1985); and (3) the association of complex trace fossils reported from the overlying Vampire Formation (Fritz et al., 1983) (Fig. 4). This assignment is strengthened by the presence of well preserved Aspidella, described previously under a number of names (see Gehling et al., 2000), and Beltanelliformis in the disc member (Fig. 7A and B). Aspidella and Beltanelliformis are known from Ediacaran strata worldwide. Associated simple trace fossils include Planolites (Fig. 7C) and Helminthoidichnites, which are among the most commonly reported trace fossils of Ediacaran age (Narbonne and Aitken, 1990; Jenkins, 1995).

Abundant small shelly fossils, including Anabarites trisulcatus and Protohertzina anabarica, that define the base of the Cambrian in the Ingta Formation were documented by Nowlan et al. (1985). Complex trace fossils, including Treptichnus pedum, Rusophycus and

Fig. 6. Field photographs of some facies associations and bounding surfaces that illustrate the range of depositional environments. (A) Ribbon-bedded argillaceous limestone and shale (FA 10) of the upper Sheepbed Formation (measuring staff at lower right is $1.5 \mathrm{~m}$ long). (B) Slope breccia (FA 11) of the Gametrail Formation, showing meter-scale slump fold (measuring staff for scale). (C) Heterolithic facies (FA 4) containing sandstone event beds with shale clasts (at arrows) and black shale interbeds, Blueflower Formation. Scale bar is $10 \mathrm{~cm}$. (D) Peritidal dolostone (FA 14) interbedded at three levels with pedogenic deposits, peritidal carbonate member, Blueflower Formation: lower arrow at rock hammer for scale where the head of the hammer is at the top of nodular, columnar, fine crystalline dolostone, middle arrow at level of red shale, upper arrow at black and green-weathering, nodular paleosols. (E) Erosional contact of red-weathering, laterally discontinuous fluvial conglomerate (FA 8) overlying shelf dolostone (FA 13), Blueflower Formation. Scale bar is $10 \mathrm{~cm}$. (F) Maroon and apple green-weathering, nodular pedogenic deposits (FA 7) of the yuletide member, Blueflower Formation (divisions on measuring staff are $10 \mathrm{~cm}$ ). (G) Karstic fill (paleokarst surface at arrow) of sandstone and phosphatic pebbles, overlying dolostone (FA 13) containing giant ooids $(10 \mathrm{~cm}$ scale bar), dolostone subunit of disc member at Section D. (H) Well bedded limestone beds (FA 15) deposited on mid to outer ramp (shelf), containing levels of phosphate (at finger) and oriented clasts of grainstone (at arrow), deposited by storm events, Ingta Formation. 


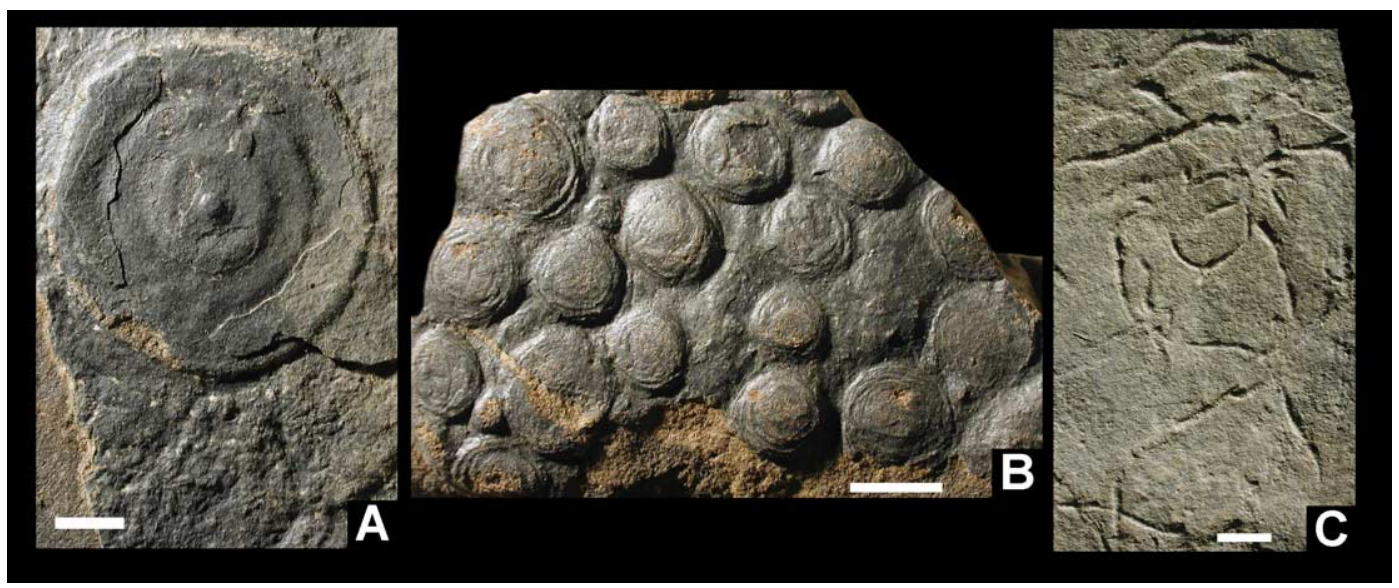

Fig. 7. Representative Ediacaran megafossils and trace fossils of the Blueflower Formation, disc member. Scale bar in each photo represents $1 \mathrm{~cm}$. (A) Aspidella terrinovica, GSC 10754, preservation on sole of bed, "masked" by black laminae, and showing elephant skin texture; (B) Beltanelliformis brunsae, GSC 10755, exceptional preservation of specimens, showing peripheral wrinkles or folds; (C) Planolites montanus, GSC 10756.

Cruziana, indicative of a sub-trilobite Cambrian age, are also present at the base of the Vampire Formation (Fritz et al., 1983). Uppermost Vampire strata, as well as basal beds of the overlying Sekwi Formation, contain trilobites of the Fallotopsis Zone, the lowest trilobite zone of the Cambrian of the Laurentia (Fritz, 1980).

\section{Reconnaissance geochemistry}

The carbon isotopic record within Neoproterozoic carbonate successions serves as a proxy for secular variation in seawater (Kaufman and Knoll, 1995). Wernecke Mountains data can be compared to a global curve for interbasinal correlation (Knoll et al., 1986) and improved resolution of climatic oscillations (Kaufman et al., 1997; Hoffman et al., 1998). In contrast with the relatively detailed isotope curve documented from the Mackenzie Mountains (Narbonne et al., 1994; Kaufman et al., 1997; James et al., 2001), sampling of the coeval succession in the Wernecke Mountains has been at a reconnaissance level. The following trends are apparent: (1) a strong negative excursion in post-glacial Ravensthroat and lower Sheepbed Formations; (2) a variable positive interval through the Sheepbed and Gametrail Formations; (3) an invariant interval through the Blueflower and Risky Formations; and (4) a sub-Cambrian negative excur- sion in the Ingta Formation. The $\delta^{13} \mathrm{C}$ profile for the Ravensthroat Formation and lower Sheepbed Formation (values from -4.1 to $-6.6 \%$ ) is similar to that of the Ravensthroat Formation in the Mackenzie Mountains (James et al., 2001) and to Marinoan cap carbonates worldwide (Kaufman and Knoll, 1995; Kaufman et al., 1997). Values from the uppermost Sheepbed and Gametrail Formations have positive values (to $+8 \%$ o ) similar to the positive interval in the coeval units within the Mackenzie Mountains (Narbonne et al., 1994; Kaufman et al., 1997). Values within the Blueflower and Risky Formations are invariant $(-1.4$ and $0.0 \%$ ) which is a similar pattern, although slightly more negative, than the correlative interval in the Mackenzie Mountains (Narbonne et al., 1994; Kaufman et al., 1997). Finally, carbon isotopic values show a pronounced negative $(-3.4 \%)$ excursion within the Ingta Formation carbonate, which is interpreted to correlate to distinctly negative values from the basal Ingta in the Mackenzies (Narbonne et al., 1994), and may correlate to the depleted interval in sub-Cambrian successions globally (Knoll and Carroll, 1999).

\section{Depositional systems and sequence stratigraphy}

The depositional history and stratigraphic architecture of the Wernecke Mountains succession are 
interpreted in a sequence stratigraphic framework. Shallow water deposits of the Blueflower Formation are sensitive recorders of relative sea level oscillations and contain more recognizable sequence boundaries than the deeper water record of the Mackenzie Mountains. The Wernecke Mountains succession is partitioned into five depositional sequences based on the position of unconformable surfaces, abrupt changes in facies, and transitions in facies stacking patterns (Fig. 8). The placement of sequence boundaries in Fig. 8 presents the most parsimonious interpretation of the succession; attempts to recognize additional or alternative sequence boundaries result in interpretations that are less logical and/or considerably more complex. The sequences, based on concepts refined by Handford and Loucks (1993), Posamentier and Allen (1999), and Plint and Nummedal (2000), consist of lowstand (LST), transgressive (TST), highstand (HST) and falling stage (FSST) systems tracts.

\subsection{Sequence 1}

Sequence 1, present completely only at Section A, is a thick, unconformity-bounded succession of the Ravensthroat, Sheepbed and Gametrail Formations (Fig. 8). Sequence boundary (SB) 1 is located at the base of the Ravensthroat Formation and is a major unconformity because glacial deposits of the Ice Brook Formation present in coeval strata in the Mackenzie Mountains are missing at this locality. The absence of glacial deposits may be attributable to non-deposition, however, the top of the Keele Formation exhibits erosion in additional to an abrupt facies change from coarse, fluvial siliciclastics of the uppermost Keele Formation (= Keele Clastic Wedge of the Mackenzie Mountains) to the cap carbonate. The subsequent post-glacial sea level rise persisted through a TST consisting of Ravensthroat carbonate overlain by the Sheepbed Formation, composed of deep-water slope facies (FA 2 and 10). A maximum flooding surface is placed high in the Sheepbed Formation near the base of the Gametrail Formation. The HST consists of FA 11 (carbonate breccia) that represents mass wasting on the slope, or highstand shedding, as sediment is exported from the interpreted prograding platform. There is little siliciclastic material within the HST, except for one unit of black shale within the Gametrail Formation. The top of Sequence 1 is SB 2, a regionally extensive paleokarst unconformity at the top of the Gametrail Formation.

\subsection{Sequence 2}

Sequence 2 is represented by the basal and peritidal carbonate members of the Blueflower Formation overlying the paleokarst unconformity. The paleokarst surface has up to $20 \mathrm{~m}$ of downward fissures and cavities filled with coarse-grained sandstone. SB 2 is best expressed at Sections A and C. It probably extends to distal sections where strata are not exposed under the interpreted LST deposits (submarine channel conglomerates, FA 1) (Fig. 8). The TST at Section D2 is formed by three retrogradational parasequences of black shale (FA 3) and heterolithic facies (FA 4). The TST also contains microbial bioherms (FA 12) with a pinnacle shape (Fig. 5D) suggestive of aggradation during a rapid sea level rise. In proximal sections, the TST contains alternations of more proximal shelf to shoreface sandstone (FA 5) and subtidal shelf dolostone and sandy dolostone (FA 13). The HST is everywhere marked by a change to peritidal carbonates (FA 14).

The FSST preserved only in distal sections (D1 and D2) is interpreted to lie at the shelf edge, where sediments of the descending shoreface are preserved (Fig. 8). The indications of falling sea level prior to the formation of SB 3 occur at the base of the FSST, where interbeds of terrestrial and fluvial deposits (FA 7 and 8) predominate and reappear within the LST of Sequence 3.

\subsection{Sequence 3}

Sequence 3 contains the greatest vertical facies changes within the Blueflower Formation and was deposited during a basinward shift of the shoreline and shut-down of the carbonate factory. The sequence also thickens distally (Fig. 8). SB 3 is a prominent unconformity where fluvial deposits cut down into peritidal carbonates (Section A), or terrestrial deposits abruptly overlie carbonates (Sections B and C) or shelf clastics (Sections D1 and D2). The LST is dominated by terrestrial (FA 7) and fluvial (FA 8) deposits of the yuletide member. The TST contains coastal deposits (FA 9) distally, preserved at the shelf margin during a relative sea level rise. Within the TST and early HST, 
North

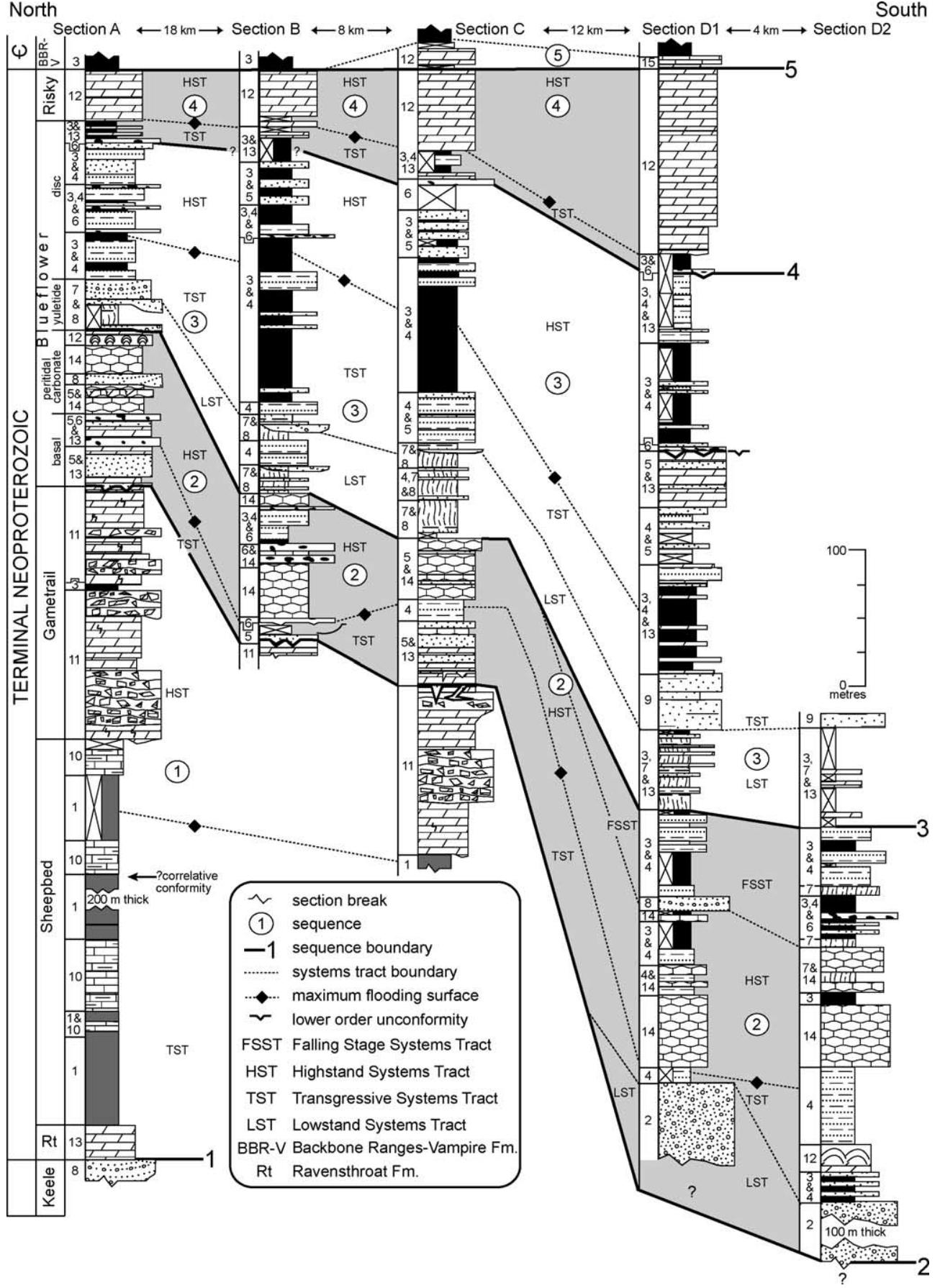

Fig. 8. Sequence stratigraphic interpretation across the transect. 
heterolithic facies (FA 4) host the Ediacaran megafossils and simple trace fossils. A maximum flooding surface is interpreted to lie within the basal part of the disc member (FA 3 and 4). Part of the early HST (FA 5 and 13) is interpreted as a carbonate-dominated, high-energy, shallow shelf and shoal environment influenced by storm waves and tidal currents. A karstic erosion surface midway through the HST in Section D1 (Figs. 6G and 8) cannot be recognized proximally. The late HST is indicated by greater proximality, evidenced by a transition from brown-weathering sandstone (FA 4) to white-weathering, cleaner quartz sandstone (FA 5), decrease in shale interbeds, and increase in SCS in addition to HCS.

\subsection{Sequence 4}

SB 4 is represented by the erosional base of a phosphatic and quartz granule conglomerate (FA 6) capped by a phosphatic hardground which indicates a rapid rise in relative sea level. SB 4 occurs in a recessive interval just below the base of the Risky Formation (Fig. 8). The transgressive lag is overlain by two or three parasequences of black shale (FA 3) with heterolithic facies (FA 4) or thin bedded dolostone (FA 13). The HST consists of the Risky Formation (FA 13), which is difficult to partition further. The sequence thins from 148 to $48 \mathrm{~m}$ northward (Fig. 8).

\subsection{Sequence 5}

SB 5 is a marked regional unconformity at the top of the Risky Formation expressed as an irregular, karstic surface extending downward at least $1.5 \mathrm{~m}$. It is overlain by well-bedded limestone (FA 15) of the Ingta Formation distally and by siliciclastic of the Backbone Ranges-Vampire Formation proximally (Fig. 8).

\subsection{Interpretation}

The five depositional sequences interpreted for the upper Windermere Supergroup suggest a landward direction or high to the north based on the truncation of sequences northward and greater accommodation space to the south evident in the southward increase of thickness of sequences in the Blueflower Formation distally. Stacking patterns and truncations of facies through the succession record the progradation of the passive margin from the Ediacaran to Cambrian through the upward transition of slope deposition in the Sheepbed and Gametrail Formations to shallow marine and terrestrial deposition in the Blueflower and Risky Formations (Fig. 9).

SB 1 truncates fluvial deposits of the Keele Clastic Wedge interpreted to incise or lie on the slope (Fig. 9A). These Keele siliciclastics represent an extreme lowering of sea level that interrupts slope deposition represented by the Twitya to Sheepbed Formations. Ice Brook glacials are absent at Section A, possibly due to non-deposition, but are known to overlie the Keele at one locality in the Wernecke Mountains (Thorkelson, 2000). SB 1 is interpreted as eustatic or glacio-eustatic in origin. Sequence 1, consisting of the Ravensthroat, Sheepbed and Gametrail Formations, records the most marked rise in relative sea level and is attributed to post-glacial transgression during continued subsidence of the margin. A correlative conformity may lie within this sequence, near the change from shale to carbonates high in the Sheepbed (Fig. 4).

A distinct depositional change (SB2) at the onset of the Blueflower Formation (Fig. 9B) records a shift of the shoreline basinward and initial dominance by siliciclastic deposition. Lowstand submarine channel deposits are preserved outboard. The HST of Sequence 2 records the aggradation and progradation of peritidal carbonates across the transect. The FSST of Sequence 2 , preserved only distally, is suggested to have formed at the shelf margin based on the interpreted coastal facies association.

SB 3 is preceded in the distal sections by indicators of falling sea level (terrestrial facies of the FSST of Sequence 2) that culminate in a great drop in base level (Fig. 9C). This drop is indicated by cratonward thinning of Sequence 3, the low depositional gradient of the LST across the transect, aggradation of terrestrial sediments, and lack of carbonate deposition. SB 3 represents the greatest depositional change from fully marine to dominantly terrestrial deposition and may be associated with erosion related to local tectonic controls. The terrestrial facies preserved across the transect are best interpreted as aggradational LST deposits. Deposition of coarse siliciclastics of the initial TST of Sequence 3 indicate a rapid rise in relative sea level, followed by a slowing of sea level rise indicated by the progradation of thicker units of 

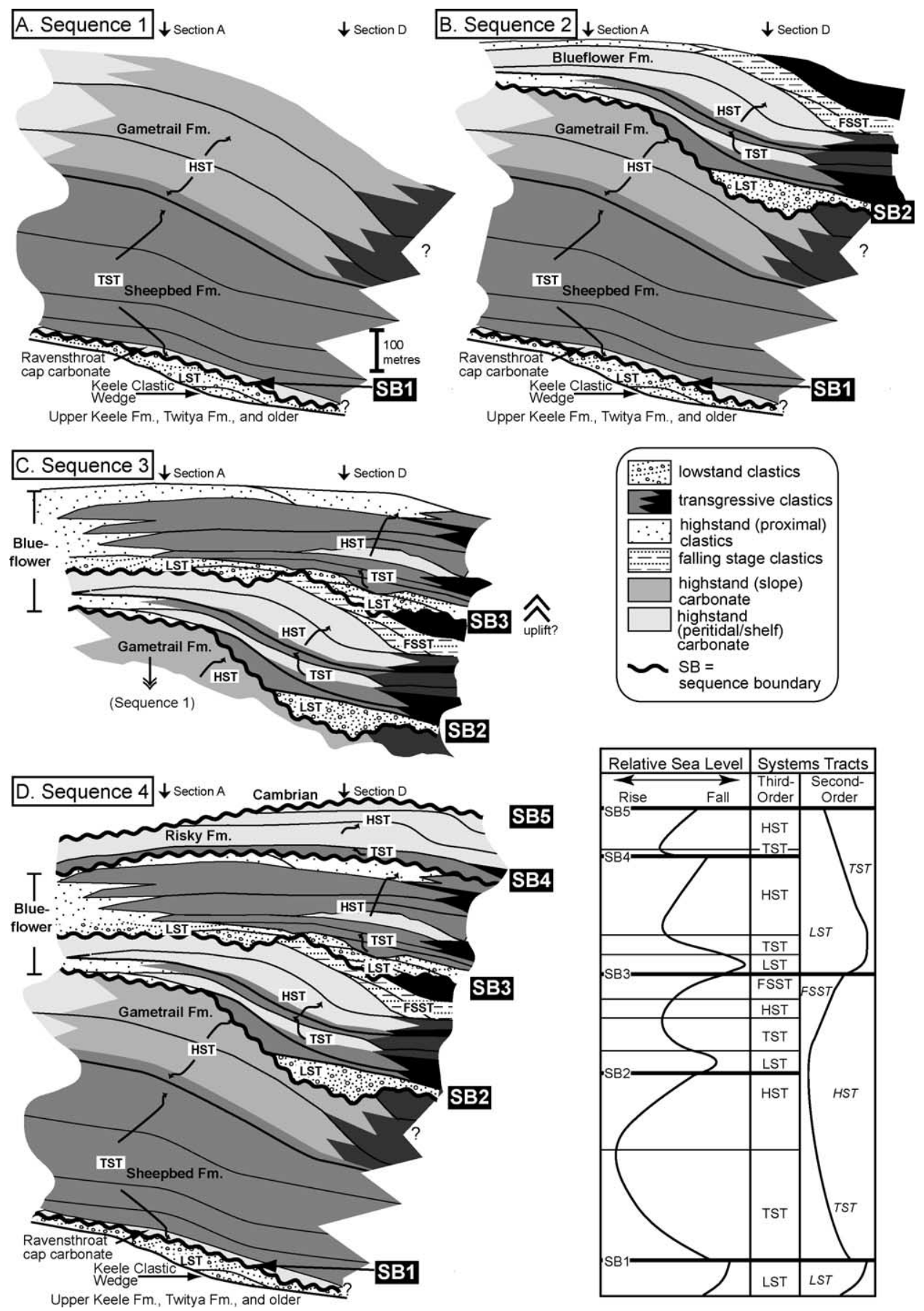

Fig. 9. Interpretation of the architecture of Sequences 1 through 5. Accompanying sea level curve is based on the sequence preserved at Section D for Sequences 2 through 5. For the economy of space, Sequence 1 is abbreviated in C. See text for discussion. 
cleaner sandstone forming the HST. In both Sequences 2 and 3, a higher-frequency cyclicity is indicated by the alternation of siliciclastic-carbonate subunits and well-developed higher-order unconformities (Figs. 4, $6 \mathrm{E}$ and $\mathrm{G})$.

SB 4 is a prominent break in deposition below the Blueflower-Risky Formation contact (Fig. 9E). The coarse sediment of the lag deposit (FA 6) indicates exposure and erosion. The Risky Formation represents the rebirth of extensive carbonate sedimentation and progradation of the platform margin. SB 5 is the sub-Cambrian unconformity. It extends across the shelf and corresponds with a major unconformity worldwide (Narbonne et al., 1994; Christie-Blick et al., 1995; Saylor et al., 1995; Pelechaty et al., 1996; Calver and Lindsay, 1998; Jiang et al., 2002; Saylor, 2003) which supports the interpretation of a eustatic origin for this boundary.

The sea-level curve (Fig. 9) is based on the thickest strata preserved distally and illustrates that the Ediacaran system in the Wernecke Mountains is bound by two significant sequence boundaries that may be useful for global correlation. Interpreted third-order and second-order patterns show the greatest rise in relative sea level occurred during Sequence 1. The greatest sea-level fall during Sequence 3 is marked by a change to a more spatially uniform stacking architecture across the transect.

\subsection{Intrabasinal sequence stratigraphic correlation}

An integrated, intrabasinal correlation of the exceptional stratigraphic record of the upper Windermere Supergroup in northwestern Canada is established. Six sequence stratigraphic tie-points can be extended from the Wernecke Mountains to the Mackenzie Mountains and are supported by a biostratigraphic and chemostratigraphic framework (Fig. 10). To facilitate discussion of both regional and global chronostratigraphic correlation, intervals of a synthesized carbon isotopic profile, based on the schemes of Pelechaty et al. (1996), Pelechaty (1998) and Saylor et al. (1998), are used as a framework. This profile is divided into anomalies, in ascending stratigraphic order from the Marinoan cap carbonates to Precambrian-Cambrian boundary: negative post-glacial $\left(\mathrm{N}_{\mathrm{pg}}\right)$, positive, invariant, and negative sub-Cambrian $\left(\mathrm{N}_{\mathrm{SC}}\right)$ (Fig. 10).
The succession of northwestern Canada corresponds to the proposed Ediacaran System, the base of which is proposed at the base of the Nuccalena Formation cap carbonate in the Adelaide Geosyncline (Terminal Proterozoic System 16th Circular, 2003). Regionally, at a second-order level, a tie-point is drawn from the base of the Ravensthroat Formation (SB1) to the base of the Ravensthroat Formation in the Mackenzies, described as sharp when overlying the Keele Clastic Wedge, or irregular when overlying Ice Brook glacials (James et al., 2001). This level is also the base of a prominent negative carbon isotopic excursion $\left(\mathrm{N}_{\mathrm{pg}}\right.$, Fig. 10). The upper boundary, at the Precambrian-Cambrian transition, is a marked regional unconformity at the top of the Risky Formation (SB 5) at most localities. Where the stratigraphy is more complete, the boundary is defined biostratigraphically at the level at which Cambrian trace fossils and small shelly fossils occur in both the Wernecke and Mackenzie Mountains (Fig. 10), and carbonates indicate the $\mathrm{N}_{\mathrm{sC}}$ excursion. Subsequent positive isotopic values in the Cambrian are not known from northwestern Canada because this interval is siliciclastic-dominated.

Four third-order sequence boundaries interpreted as tie-points occur between the two second-order bounding surfaces in both the Wernecke and Mackenzie Mountains (Fig. 10). A correlative conformity was postulated to lie high in the Sheepbed Formation (Dalrymple and Narbonne, 1996) and a tentative correlation is extended to a similar level in the deep-water succession in the Wernecke Mountains, within the positive interval. SB 2, 3, and 4 lie in the invariant interval. The apparent regional unconformity at the base of the Blueflower Formation (SB 2) is correlated with a similar level in the lower Blueflower Formation in the Mackenzie Mountains, a level designated as a simple sequence boundary (containing no higher-order boundaries) by MacNaughton et al. (2000) who perhaps underestimated the significance of this surface in the deeper-water succession. Tie-points are extended from SB 3 and 4 to points in the Blueflower Formation in the Mackenzie Mountains, both of which are interpreted as prominent basinward shifts of a siliciclastic source. SB 4 correlates to a sub-Risky Formation unconformity recognized by MacNaughton et al. (2000) and indicates a fall in relative sea level even more pronounced than SB 


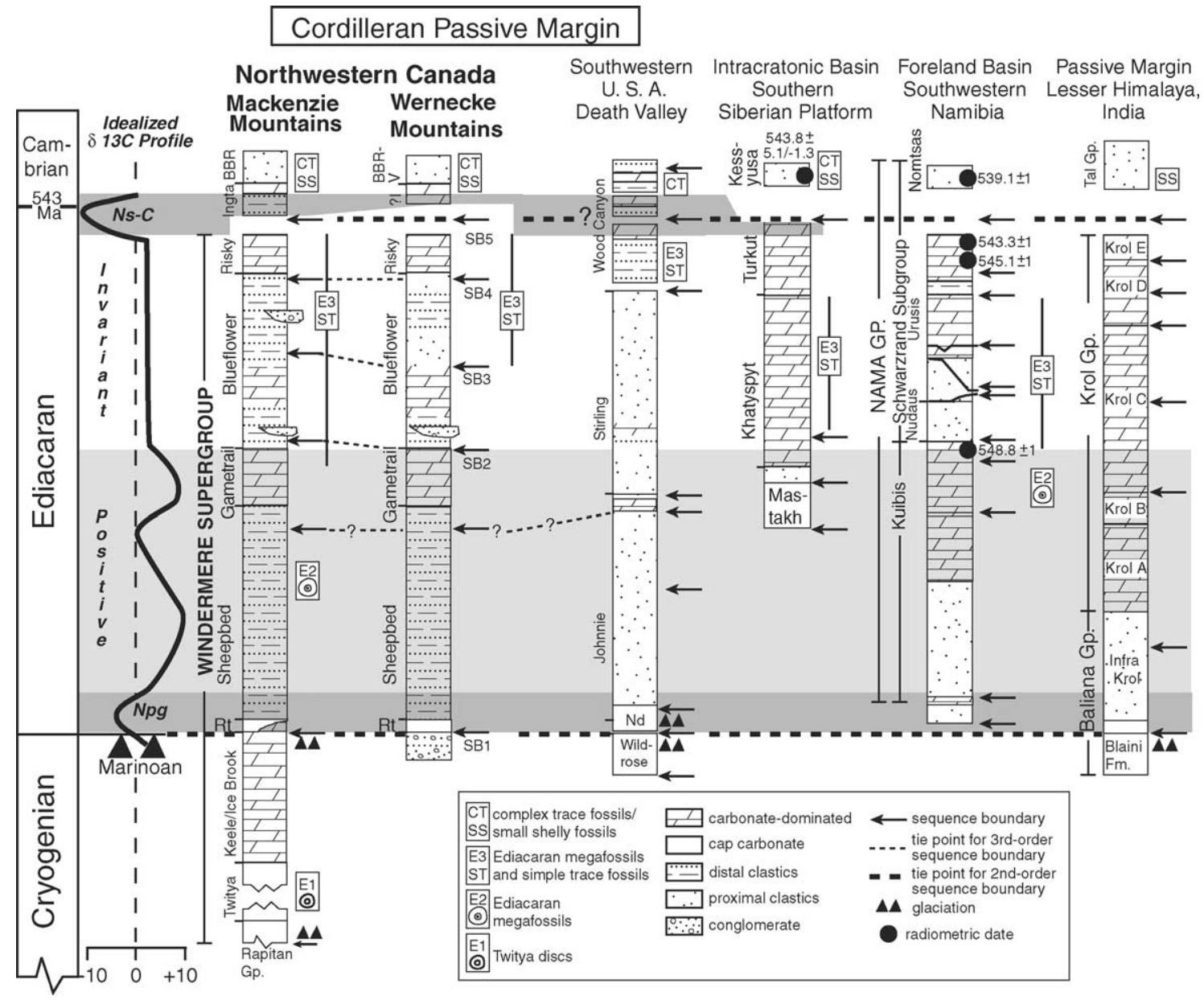

Fig. 10. Global correlation of terminal Neoproterozoic mixed siliciclastic-carbonate successions within a chemostratigraphic framework of carbon-isotopic intervals based on a synthesized profile (after Pelechaty et al., 1996; Pelechaty, 1998; Saylor et al., 1998). Synthesized curve is based on the Mackenzie Mountains (after Kaufman et al., 1997; James et al., 2001). The fossil zonation of E1 representing simple discs, E2 representing larger, radially symmetrical discs and fronds and E3 representing complex discs, fronds, dickinsoniids, and abundant trace fossils is after Narbonne et al. (1994). Lithologies of sections are greatly simplified and no thicknesses are implied. Sections: Siberia: absolute date from Bowring et al. (1993), stratigraphy after Knoll et al. (1995), Pelechaty et al. (1996), and Pelechaty (1998); Namibia: absolute dates from Grotzinger et al. (1995), stratigraphy after Saylor et al. (1998) and Saylor (2003) and references therein; India: stratigraphy and preliminary isotopic data from Jiang et al. (2002); Southeast USA: Nd = Noonday Dolomite, sequence stratigraphy after Fedo and Cooper (2001), stratigraphy and chemostratigraphic data after Corsetti and Hagadorn (2000) and Prave (1999); Mackenzie Mountains: Rt $=$ Ravensthroat cap carbonate, BBR = Backbone Ranges Formation, stratigraphy and sequence boundaries after Narbonne and Aitken (1995), MacNaughton et al. (2000) and Dalrymple and Narbonne (1996); isotopic trends after Narbonne et al. (1994) and Kaufman et al. (1997); Wernecke Mountains based on this present study, BBR-V = Backbone Ranges-Vampire Formation.

5 at the top of the Risky Formation. MacNaughton et al. (2000) further suggested that the concentration of unconformities through the Blueflower Formation may be consistent with a period of thermal uplift coeval to extensional tectonism in the southern Canadian Cordillera that accounts for renewed subsidence in the Cambrian (Bond and Kominz, 1984; Bond et al., 1985). Although these repeated sea level falls through the late Ediacaran may be eustatic in nature, the intrabasinal correlation of prominent basinward shifts indicated by SB 3, 4, and 5 may support the hypothesis of a regional tectonic event such as uplift. 


\section{Global correlations}

The integrated stratigraphy of northwestern Canada has several trends of possible global importance (Fig. 10). The base of the Ediacaran System is interpreted to lie directly beneath Marinoan cap carbonates, which appear to be high-resolution global markers (Knoll et al., 1986; Narbonne et al., 1994; Narbonne and Aitken, 1995; Kaufman et al., 1997; Hoffman et al., 1998; Kennedy et al., 1998; Walter et al., 2000). The Ediacaran is bounded at the top by the Precambrian-Cambrian boundary, a major unconformity at most sections worldwide which suggests a eustatic origin. The age of this boundary (ca. $543 \mathrm{Ma}$ ) is based on U-Pb zircon dates from Namibia (Grotzinger et al., 1995), Siberia (Bowring et al., 1993) and Oman (Amthor et al., 2003). Testing the timing of multiple, globally synchronous glacial events by radiometric dating has not been possible (Evans, 2000). Thus, the best possible chronostratigraphic resolution comes from integrated stratigraphic approaches.

In northwestern Canada, the Ediacaran is constrained within the four well-resolved carbon-isotopic intervals and provides an independent test of utilizing integrated stratigraphy, particularly the linkage of third-order sequence boundaries beyond regional correlation. Comparison is drawn with mixed siliciclastic-carbonate successions that have similarly integrated chronostratigraphies. These include differing tectonic regimes such as the intracratonic-basin setting of Siberia (Pelechaty, 1998), foreland basin of Namibia (Saylor et al., 1998), and passive margin settings of India (Jiang et al., 2002), the southern Cordillera (Corsetti and Hagadorn, 2000) and northwestern Canada (Fig. 10).

SB 5, the sub-Cambrian unconformity, is readily recognizable in all of the sections. Its duration and magnitude vary between sections, but the age appears to be the same within the precision afforded by biostratigraphic and chemostratigraphic correlation. In North America, SB 5 correlates to the base of the Sauk Sequence (of Sloss, 1963) at or near the base of the Cambrian. The sharp $\mathrm{N}_{\mathrm{sC}}$ excursion that is immediately below or approximates the Precambrian-Cambrian transition (Siberia, southwestern United States, northwestern Canada) is not present due to erosion or non-deposition as in Namibia and possibly India. The $\mathrm{N}_{\mathrm{SC}}$ excursion is defined by a $\mathrm{U}-\mathrm{Pb}$ zircon age of $542.0 \pm 0.3 \mathrm{Ma}$ in Oman (Amthor et al., 2003). Globally, the calcified metazoans Cloudina and Namacalathus occur only below this interval while small shelly fossils and complex trace fossils first appear with or above the negative excursion (Fig. 10). In the southern Great Basin, United States, the Precambrian-Cambrian boundary is defined by the first appearance of T. pedum and other complex trace fossils within the $\mathrm{N}_{\mathrm{sC}}$ interval (Corsetti and Hagadorn, $2000,2003)$. Correlation of the sub-Cambrian unconformity is extended to the regional disconformity that defines the middle member of the Wood Canyon Formation (Fedo and Cooper, 2001) (Fig. 10). Other carbonate dominated, Precambrian-Cambrian boundary successions that contain the $\mathrm{N}_{\mathrm{SC}}$ isotopic event include Oman (Amthor et al., 2003), China (Lambert et al., 1987), Mongolia (Brasier et al., 1996), and Morocco (Tucker, 1986).

SB 4 is easily correlated into the Mackenzie Mountains. Sequence boundaries occur at or near the same level as SB4 (high in the invariant interval) in Death Valley, Namibia, and India (Fig. 10), but the absence of unique features at this boundary or independent means of correlation do not presently permit precise correlation between boundaries. There does not appear to be a sequence boundary at this level on the Siberian Platform (Knoll et al., 1995; Pelechaty et al., 1996; Pelechaty, 1998).

SB 3 also has demonstrable correlation with the Mackenzie Mountains, but cannot be correlated with confidence outside the Canadian Cordillera. It is just above this level in the Wernecke Mountains where the most diverse E3 megafossils and simple trace fossils occur, which provides a coarse correlation to levels in Siberia and Namibia (Fig. 10). Dates from Namibia suggests the duration of the invariant and $\mathrm{N}_{\mathrm{sC}}$ intervals may be 5-6 million years (Saylor et al., 1998). There are a varying number of sequence boundaries at this level in Namibia (Saylor et al., 1998) and India (Jiang et al., 2002), of both interpreted tectonic and eustatic nature, which hinders the linkage of these surfaces.

SB 2 and its correlative surface in the Mackenzie Mountains lie in a position immediately above the positive interval. Sequence boundaries are reported at or near this level in Siberia, Namibia, and India (Krol B/C level) (Fig. 10) and further research should be carried out in other areas to determine if this represents 
a global eustatic signal. Below the level of SB 2 in northwestern Canada, sequence boundaries are not as obvious in the deep-water strata except for one level high in the Sheepbed Formation which is questionably extended to a level high in the Johnnie Formation. In the other successions, a variable number of boundaries are identified.

At the level of the positive interval in the Mackenzie Mountains, the E2 biota (Ediacaran megafossils, restricted to discs and fronds) occurs in the Sheepbed Formation and the first occurrence of simple trace fossils and the E3 biota occur just below the surface correlative with SB2. Another biostratigraphic constraint that may characterize this interval is the range of calcified metazoans such as Cloudina and Namacalathus that begins within the positive interval in the Nama Group (Grotzinger et al., 2000) and possibly in the Stirling Quartzite of the southeastern United States (Grant, 1990). These fossils extend through the invariant and $\mathrm{N}_{\mathrm{SC}}$ interval where their last appearance coincides with the Precambrian-Cambrian boundary (Amthor et al., 2003).

SB 1 lies at the base of the Ediacaran and coincides with the base of the $\mathrm{N}_{\mathrm{pg}}$ interval in northwestern Canada (base of the Ravensthroat Formation). This level correlates with the base of the Nuccalena Formation in Australia which is interpreted as a disconformity (Christie-Blick et al., 1995) and the unit has distinctive negative carbon isotopic values (Calver, 2000; Walter et al., 2000). A correlation is extended to the base of the Noonday Dolomite cap carbonate that unconformably overlies the Wildrose Diamictite (upper Kingston Peak Formation), interpreted as coeval to the Marinoan event (Prave, 1999). A similar correlation can be extended to the cap carbonate overlying diamictite of the Blaini Formation in India (Fig. 10).

Based on our integrated correlation within the exceptional succession of northwestern Canada, it appears that sequence stratigraphy provides a robust and presently under-utilized tool for regional correlation in the terminal Neoproterozoic. Global sequence-stratigraphic correlations seem tantalizingly possible, but at present are hampered by differences in tectonic settings of depositional basins and hence thicknesses of sequences, absence of unique features that might characterize a particular sequence boundary, and a scarcity of independent means of correlation of sequence boundaries. The presence of sequence boundaries at the base and top of the Ediacaran system in many sections enhances the definition and correlation of this newly named system. Sequence boundaries lie at the base of both the $\mathrm{N}_{\mathrm{sC}}$ and $\mathrm{N}_{\mathrm{pg}}$ intervals which refines correlations. The sequence boundaries that coincide with the top of the positive interval in several localities and at a level within the positive interval may be tested as global boundaries. Linkages of third-order sequence boundaries are not straightforward, but when integrated with biostratigraphy and chemostratigraphy, a more comprehensive chronostratigraphy is coming into focus to constrain events of the terminal Neoproterozoic.

\section{Summary and conclusions}

1. The lithostratigraphy of the upper Windermere Supergroup (Ravensthroat to Risky Formations) is established in the Wernecke Mountains. The succession spans the Ediacaran System. The Sheepbed, Gametrail and Risky Formations are correlated to their lithological equivalents in the Mackenzie Mountains. Strata herein referred to the Blueflower Formation represent shallow-water equivalents to slope deposits of the Mackenzies succession.

2. Biostratigraphic correlation between the Wernecke and Mackenzie Mountains is based on Ediacaran megafossils and simple trace fossils from the Blueflower Formation, and occurrence of Cambrian small shelly fossils and complex trace fossils in post-Windermere strata.

3. Reconnaissance carbon isotopic values from the Wernecke Mountains correlate to four intervals of a synthesized $\delta^{13} \mathrm{C}$ profile from the Mackenzie Mountains. In ascending stratigraphic order these include: (1) a negative post-glacial $\left(\mathrm{N}_{\mathrm{pg}}\right)$ interval in the Ravensthroat Formation and lower Sheepbed Formation; (2) a variable positive interval through the Sheepbed and Gametrail Formations; (3) an invariant interval though the Blueflower and Risky Formations; and (4) a negative sub-Cambrian $\left(\mathrm{N}_{\mathrm{SC}}\right)$ excursion in post-Windermere carbonate.

4. The Wernecke Mountains succession is partitioned into 5 depositional sequences. Second- and third-order sequence boundary tie points are correlated with the overall deeper-water succession of 
the Mackenzie Mountains. Correlation is corroborated within an integrated framework, using fossils and isotopic variations to establish a coherent, Ediacaran chronostratigraphy in northwestern Canada.

5. The chronostratigraphy for northwestern Canada can be correlated to mixed siliciclastic-carbonate successions worldwide. The correlation of the Ediacaran System may be enhanced by sequence boundaries at the base and top of the system, while linkages of third-order sequence boundaries are hindered between basins of differing tectonic settings. In constructing a global Ediacaran chronostratigraphy, sequence stratigraphy improves the resolution of correlation when integrated with biostratigraphic and chemostratigraphic data.

\section{Acknowledgements}

This work was funded by Natural Sciences and Engineering Research Council operating grants to G.M.N., N.P.J. and R.W.D. and NSF grants EAR 98-17348, EAR 01-26378 and NASA Exobiology grant NAG 512337 to A.J.K. We thank Grant Abbott at the Yukon Geological Survey and Derek Thorkelson at Simon Fraser University for sharing expenses of helicopter time. We gratefully acknowledge the exceptional service provided by Canadian Helicopters, Norman Wells, Northwest Territories. Mike Boddy provided excellent assistance in the field. The manuscript was improved by reviews by M.C. Pope and B.Z. Saylor.

\section{References}

Aitken, J.D., 1984. Strata and trace fossils near the PrecambrianCambrian boundary, Mackenzie, Selwyn, and Wernecke Mountains, Yukon and Northwest territories: discussion. Current Research, Part B, Geological Survey of Canada, Paper 84-1B, pp. 401-407.

Aitken, J.D., 1989. Uppermost Proterozoic Formations in central Mackenzie Mountains, Northwest Territories. Geol. Surv. Can. Bull. 368, 1-26.

Aitken, J.D., 1991a. The Ice Brook Formation and post-Rapitan, Late Proterozoic glaciation, Mackenzie Mountains, Northwest Territories. Geol. Surv. Can. Bull. 404, 1-43.

Aitken, J.D., 1991b. Two Late Proterozoic glaciations, Mackenzie Mountains, northwestern Canada. Geology 19 (5), 445-448.
Amthor, J.E., et al., 2003. Extinction of Cloudina and Namacalathus at the Precambrian-Cambrian boundary in Oman. Geology 31 (5), 431-434.

Bond, G.C., Christie-Blick, N., Kominz, M.A., Devlin, W.J., 1985. An early Cambrian rift to post-rift transition in the Cordillera of western North America. Nature 315 (6022), 742-745.

Bond, G.C., Kominz, M.A., 1984. Construction of tectonic subsidence curves for the early Paleozoic miogeocline, southern Canadian Rocky Mountains: implications for subsidence mechanisms, age of break-up, and crustal thinning. Geol. Soc. Am. Bull. 95, 155-173.

Bowring, S.A., et al., 1993. Calibrating rates of early Cambrian evolution. Science 261 (5126), 1293-1298.

Brasier, M.D., Sheilds, G., Kuleshov, V.N., Zhegallo, E.A., 1996. Integrated chemo- and biostratigraphic calibration of early animal evolution: Neoproterozoic-early Cambrian of southwest Mongolia. Geol. Mag. 133 (4), 445-485.

Calver, C.R., 2000. Isotope stratigraphy of the Ediacarian (Neoproterozoic III) of the Adelaide Rift Complex, Australia, and the overprint of water column stratification. Precambrian Res. 100, 121-150.

Calver, C.R., Lindsay, J.F., 1998. Ediacaran sequence and isotope stratigraphy of the Officer Basin, South Australia. Aust. J. Earth Sci. 45, 513-532.

Christie-Blick, N., Dyson, I.A., von der Borch, C.C., 1995. Sequence stratigraphy and the interpretation of Neoproterozoic earth history. Precambrian Res. 73 (1-4), 3-26.

Colpron, M., Logan, J.M., Mortensen, J.K., 2002. U-Pb zircon age constraint for late Neoproterozoic rifting and initiation of the lower Paleozoic passive margin of western Laurentia. Can. J. Earth Sci. 39 (2), 133-143.

Coniglio, M., Dix, G.R., 1992. Carbonate slopes. In: Walker, R.G., James, N.P. (Eds.), Facies Models: Response to Sea-Level Change. Geological Association of Canada, St. John's, pp. 349-374.

Conway Morris, S., Fritz, W.H., 1980. Shelly microfossils near the Precambrian-Cambrian boundary, Mackenzie Mountains, northwestern Canada. Nature 286 (5771), 381-384.

Corsetti, F.A., Hagadorn, J.W., 2000. Precambrian-Cambrian transition: Death Valley, United States. Geology 28, 299-302.

Corsetti, F.A., Hagadorn, J.W., 2003. The Precambrian-Cambrian transition in the Southern Great Basin U.S.A. Sediment. Record 1 (1), 4-8.

Dalrymple, R.W., Narbonne, G.M., 1996. Continental slope sedimentation in Sheepbed Formation (Neoproterozoic, Windermere Supergroup), Mackenzie Mountains, N.W.T. Can. J. Earth Sci. 33 (6), 848-862.

Eisbacher, G.H., 1981. Sedimentary tectonics and glacial record in the Windermere Supergroup, Mackenzie Mountains, northwestern Canada. Geological Survey of Canada, Paper 80-27, pp. 1-40.

Eisbacher, G.H., 1985. Late Proterozoic rifting, glacial sedimentation, and sedimentary cycles in the light of Windermere deposition, western Canada. Palaeogeogr., Palaeoclimatol., Palaeoecol. 51 (1-4), 231-254.

Evans, D.A.D., 2000. Stratigraphic, geochronological, and paleomagnetic constraints upon the Neoproterozoic climatic paradox. Am. J. Sci. 300, 347-433. 
Fedo, C.M., Cooper, J.D., 2001. Sedimentology and sequence stratigraphy of Neoproterozoic and Cambrian units across a craton-margin hinge zone, southeastern California, and implications for the early evolution of the Cordilleran margin. Sediment. Geol. 141/142, 501-522.

Fritz, W.H., 1980. International Precambrian-Cambrian Boundary Working Group's 1979 field study to Mackenzie Mountain, Northwest Territories, Canada. Geological Survey of Canada, Paper 80-1A, pp. 41-45.

Fritz, W.H., Narbonne, G.M., Gordey, S.P., 1983. Strata and trace fossils near the Precambrian-Cambrian boundary, Mackenzie, Selwyn, and Wernecke Mountains, Yukon and Northwest territories. Current Research, Part B, Geological Survey of Canada, Paper 83-1B, pp. 365-375.

Fritz, W.H., Narbonne, G.M., Gordey, S.P., 1984. Strata and trace fossils near the Precambrian-Cambrian boundary, Mackenzie, Selwyn, and Wernecke Mountains, Yukon and Northwest territories: reply. Current Research, Part B, Geological Survey of Canada, Paper 84-1B, pp. 409-412.

Gabrielse, H., Blusson, S.L., Roddick, J.A., 1973. Geology of Flat River, Glacier Lake, and Wrigley Lake map-areas, District of Mackenzie and Yukon Territory. Geol. Surv. Can., Memoir 366, $1-153$.

Gehling, J.G., Narbonne, G.M., Anderson, M.M., 2000. The first named Ediacaran body fossil, Aspidella terranovica. Palaeontology 43, 427-456.

Glaessner, M.A., 1984. The Dawn of Animal Life. Cambridge University Press, Cambridge, 244 pp.

Grant, S.W.F., 1990. Shell structure and distribution of Cloudina, a potential index fossil for the terminal Proterozoic. Am. J. Sci. 290-A, 261-294.

Grotzinger, J.P., Bowring, S.A., Saylor, B.Z., Kaufman, A.J., 1995. Biostratigraphic and geochronologic constraints on early animal evolution. Science 270, 598-604.

Grotzinger, J.P., Watters, W.A., Knoll, A.H., 2000. Calcified metazoans in thrombolitic stromatolite reefs of the terminal Proterozoic Nama Group, Namibia. Paleobiology 26 (3), 334359.

Handford, C.R., Loucks, R.G., 1993. Carbonate depositional sequences and systems tracts; responses of carbonate platforms to relative sea-level changes. In: Loucks, R.G., Sarg, J.F. (Eds.), Carbonate Sequence Stratigraphy; Recent Developments and Applications. AAPG Memoir 57, 3-41.

Harlan, S.S., Heaman, L., LeCheminant, A.N., Premo, W.R., 2003. Gunbarrel mafic magmatic event: a key 780 Ma time marker for Rodinia plate reconstructions. Geology 31 (12), 1053-1056.

Hoffman, P.F., Kaufman, A.J., Halverson, G.P., Schrag, D.P., 1998. A Neoproterozoic snowball earth. Science 281 (5381), 13421346.

Hofmann, H.J., 1981. First record of a Late Proterozoic faunal assemblage in the North American Cordillera. Lethaia 14 (4), 303-310.

Hofmann, H.J., 1984. Organic-walled microfossils from the latest Proterozoic and earliest Cambrian of the Wernecke Mountains, Yukon. Current Research, Part B, Geological Survey of Canada, Paper 84-1B, pp. 285-297.

Hofmann, H.J., Fritz, W.H., Narbonne, G.M., 1983. Ediacaran (Precambrian) fossils from the Wernecke Mountains, northwestern Canada. Science 221 (4609), 455-457.
Hofmann, H.J., Narbonne, G.M., Aitken, J.D., 1990. Ediacaran remains from intertillite beds in northwestern Canada. Geology 18, 1199-1202.

James, N.P., Narbonne, G.M., Kyser, T.K., 2001. Late Neoproterozoic cap carbonates: Makenzie Mountains, northwestern Canada: precipitation and global glacial meltdown. Can. J. Earth Sci. 38 (8), 1229-1262.

Jenkins, R.J.F., 1995. The problems and potential of using animal fossils and trace fossils in terminal Proterozoic biostratigraphy. Precambrian Res. 73 (1), 51-69.

Jiang, G., Christie-Blick, N., Kaufman, A.J., Banerjee, D.M., Rai, V., 2002. Sequence stratigraphy of the Neoproterozoic Infra Krol Formation and Krol Group, Lesser Himalaya, India. J. Sediment. Res. 72 (4), 524-542.

Kaufman, A.J., Knoll, A.H., 1995. Neoproterozoic variations in the carbon isotopic composition of seawater: stratigraphic and biogeochemical implications. Precambrian Res. 73 (1), 27-49.

Kaufman, A.J., Knoll, A.H., Narbonne, G.M., 1997. Isotopes, ice ages, and terminal Proterozoic earth history. Proc. Natl. Acad. Sci. U.S.A. 94, 6600-6605.

Kennedy, M.J., Runnegar, B., Prave, A.R., Hoffmann, K.-H., Arthur, M.A., 1998. Two or four Neoproterozoic glaciations? Geology 26 (12), 1059-1063.

Knoll, A.H., Carroll, S.B., 1999. Early animal evolution: emerging views from comparative biology and geology. Science 284 (5423), 2129-2137.

Knoll, A.H., Grotzinger, J.P., Kaufman, A.J., Kolosov, P., 1995. Integrated approaches to terminal Proterozoic stratigraphy: an example from the Olenek Uplift, northeastern Siberia. Precambrian Res. 73 (1), 251-270.

Knoll, A.H., Hayes, J.M., Kaufman, A.J., Swett, K., Lambert, I.B., 1986. Secular variation in carbon isotope ratios from Upper Proterozoic successions of Svalbard and East Greenland. Nature 321 (6073), 832-839.

Knoll, A.H., Walter, M.R., 1992. Latest Proterozoic stratigraphy and Earth history. Nature 356 (6371), 673-678.

Lambert, I.B., Walter, M.R., Wenlong, Z., Songnian, L., Guogan, M., 1987. Paleoenvironment and carbon isotope stratigraphy of Upper Proterozoic carbonates of the Yangtze Platform. Nature 325 (6101), 140-142.

MacNaughton, R.B., Narbonne, G.M., 1999. Evolution and ecology of Neoproterozoic-lower Cambrian trace fossils, NW Canada. Palaios 14 (2), 97-115.

MacNaughton, R.B., Dalrymple, R.W., Narbonne, G.M., 1997. Multiple orders of relative sea-level change in an earliest Cambrian passive-margin succession, Mackenzie Mountains, northwestern Canada. J. Sediment. Res. 67 (4), 622-637.

MacNaughton, R.B., Narbonne, G.M., Dalrymple, R.W., 2000. Neoproterozoic slope deposits, Mackenzie Mountains, northwestern Canada; implications for passive-margin development and Ediacaran faunal ecology. Can. J. Earth Sci. 37 (7), 997-1020.

Narbonne, G.M., 1998. The Ediacara Biota: a terminal Neoproterozoic experiment in the evolution of life. GSA Today 8 (2), 1-6.

Narbonne, G.M., Aitken, J.D., 1990. Ediacaran fossils from the Sekwi Brook area, Mackenzie Mountains, northwestern Canada. Palaeontology 33 (4), 945-980. 
Narbonne, G.M., Aitken, J.D., 1995. Neoproterozoic of the Mackenzie Mountains, northwestern Canada. Precambrian Res. 73 (1-4), 101-121.

Narbonne, G.M., Gehling, J.G., 2003. Life after snowball: the oldest complex Ediacaran fossils. Geology 31 (1), 27-30.

Narbonne, G.M., Hofmann, H.J., 1987. Ediacaran biota of the Wernecke Mountains, Yukon, Canada. Palaeontology 30 (4), 647-676.

Narbonne, G.M., Hofmann, H.J., Aitken, J.D., 1985. PrecambrianCambrian boundary sequence, Wernecke Mountains, Yukon Territory. Current Research, Part A, Geological Survey of Canada, Paper 85-1A, pp. 603-608.

Narbonne, G.M., Kaufman, A.J., Knoll, A.H., 1994. Integrated chemostratigraphy and biostratigraphy of the Windermere Supergroup, northwestern Canada: implications for Neoproterozoic correlations and the early evolution of animals. Geol. Soc. Am. Bull. 106 (10), 1281-1292.

Nowlan, G.S., Narbonne, G.M., Fritz, W.H., 1985. Small shelly fossils and trace fossils near the Precambrian-Cambrian boundary in the Yukon Territory, Canada. Lethaia 18 (3), 233256.

Osborne, D.T., Narbonne, G.M., Carrick, J., 1986. Stratigraphic and economic potential of Precambrian-Cambrian boundary strata, Wernecke Mountains, east-central Yukon. Yukon Geol. 1, 131-138.

Pelechaty, S.M., 1998. Integrated chronostratigraphy of the Vendian System of Siberia: implications for a global stratigraphy. J. Geol. Soc. London 155 (6), 957-973.

Pelechaty, S.M., Grotzinger, J.P., Kashirtsev, V.A., Zhernovsky, V.P., 1996. Chemostratigraphic and sequence stratigraphic constraints on Vendian-Cambrian basin dynamics, northeast Siberian Craton. J. Geol. 104 (3), 543-563.

Plint, A.G., Nummedal, D., 2000. The falling stage systems tract: recognition and importance in sequence stratigraphic analysis. In: Hunt, D., Gawthorpe, R.L. (Eds.), Sedimentary Responses to Forced Regression. Geological Society of London, Special Publication No. 172, pp. 1-17.

Posamentier, H.W., Allen, G.P., 1999. Siliciclastic Sequence Stratigraphy-Concepts and Applications. Concepts in Sedimentology and Paleontology No. 7. SEPM, Tulsa, 210 pp.
Prave, A.R., 1999. Two diamictites two cap carbonates, two d13C excursions, two rifts: the Neoproterozoic Kingston Peak Formation, Death Valley, California. Geology 27 (4), 339-342.

Ross, G.M., 1991. Tectonic setting of the Windermere Supergroup revisited. Geology 19 (11), 1125-1128.

Ross, G.M., Bloch, J.D., Krouse, H.R., 1995. Neoproterozoic strata of the southern Canadian Cordillera and the isotopic evolution of seawater sulfate. Precambrian Res. 73 (1-4), 71-99.

Saylor, B.Z., 2003. Sequence stratigraphy and carbonatesiliciclastic mixing in a terminal Proterozoic foreland basin, Urusis Formation, Nama Group, Namibia. J. Sediment. Res. 73 (2), 264-279.

Saylor, B.Z., Grotzinger, J.P., Germs, G.J.B., 1995. Sequence stratigraphy and sedimentology of the Neoproterozoic Kuibus and Schwarzrand Subgroups (Nama Group), southwestern Namibia. Precambrian Res. 73 (1-4), 153-171.

Saylor, B.Z., Kaufman, A.J., Grotzinger, J.P., Urban, F., 1998. A composite reference section for terminal Proterozoic strata of southern Namibia. J. Sediment. Res. 68 (6), 1223-1235.

Sloss, L.L., 1963. Sequences in the cratonic interior of North America. Geol. Soc. Am. Bull. 74, 93-114.

Sohl, L.E., Christie-Blick, N., Kent, D.V., 1999. Paleomagnetic polarity reversals in Marinoan (ca. $600 \mathrm{Ma}$ ) glacial deposits of Australia: implications for the duration of low-latitude glaciation in Neoproterozoic time. Geol. Soc. Am. Bull. 111 (8), 1120-1139.

Terminal Proterozoic System 16th Circular, 2003. http://geol. queensu.ca/people/narbonne/trm-prot/, March.

Thorkelson, D.J., 2000. Geology and mineral occurrences of the Slats Creek, Fairchild Lake and "Dolores Creek" areas, Wernecke Mountains (106D/16, 106C/13, 106C/14). Explor. Geol. Services Division, Yukon Region, Bull. 10, 1-73.

Tucker, M.E., 1986. Carbon isotopic excursions in Precambrian/ Cambrian boundary beds Morocco. Nature 319 (6048), 48-50.

Walter, M.R., Veevers, J.J., Calver, C.R., Gorjan, P., Hill, A.C., 2000. Dating the 840-544 Ma Neoproterozoic interval by isotopes of strontium, carbon and sulfur in seawater, and some interpretive models. Precambrian Res. 100 (1-3), 371-433.

Young, G.M., 1992. Late Proterozoic stratigraphy and the Canada-Australia connection. Geology 20 (8), 215-218. 